\title{
Groundwater circulation and earthquake-related changes in hydrogeological karst environments: a case study of the Sibillini Mountains (central Italy) involving artificial tracers
}

\author{
T. Nanni ${ }^{1}$ • P. M. Vivalda ${ }^{1} \cdot$ S. Palpacelli ${ }^{2}$ M. Marcellini ${ }^{1} \cdot$ A. Tazioli $^{1}$ (I) \\ Received: 27 September 2019 / Accepted: 26 June 2020 / Published online: 21 July 2020 \\ (C) The Author(s) 2020, corrected publication 2020
}

\begin{abstract}
Using artificial tracer tests, this study confirms the presence of a single basal aquifer feeding the springs in the wide and complex hydrogeological boundary of the Sibillini Mountains of central Italy. The tracer was introduced into the sinkhole of the Castelluccio di Norcia plain. The tracer test results, observed at the studied springs, highlight the changes induced by the 2016/2017 earthquake in the water circulation of the aquifer system. In particular, the seismic events increased the hydraulic conductivity of the basal aquifer, with a consequent increase in the springs' flow rates at the western hydrogeological boundary and a decrease in the flow rates at the eastern Adriatic hydrogeological boundary. This phenomenon is in accordance with the hydro-structural framework of the area. The study also investigated the relation between groundwater circulation and tracer behaviour in the springs during the pre- and post-earthquake periods. The tracer test results led to the formulation of hypotheses about water circulation of the area. The trend of the tracer breakthrough curves demonstrates that the upper portion of the basal aquifer is characterised by fast water circulation similar to that in the epiphreatic area of karst aquifers, while a slow circulation due to fissures with interconnected drains occurs in the deepest portion of the aquifers. The obtained results highlight how tectonics and karst can affect the hydrogeological setting of the Apennine carbonate chain; in particular, the seismicity of central Italy may alter groundwater circulation for a long period of time when great magnitude earthquakes occur.
\end{abstract}

Keywords Carbonate rocks $\cdot$ Earthquake $\cdot$ Fractured rocks $\cdot$ Tracer tests $\cdot$ Italy

\section{Introduction and purpose of the work}

This study examines the characteristics of groundwater flow paths in the very large hydrogeological complex of the Sibillini Mountains (extended over approximately $60 \mathrm{~km}^{2}$ ), located in the southern area of the Umbria-Marche Apennines in Italy (Fig. 1), which is characterised by a complicated morphological and structural setting (Giovagnotti 1975; Coltorti and Farabollini 1995; Pierantoni et al. 2013; Aringoli et al. 2014), a vast areal extension and a complex

A. Tazioli

a.tazioli@staff.univpm.it

1 Università Politecnica delle Marche, department SIMAU, via Brecce Bianche 12, 60131 Ancona, Italy

2 Treia, Italy hydro-stratigraphy with several separate aquifers (Boni et al. 1986; Boni 2010).

The aquifers feed springs with flow rates higher than $0.6 \mathrm{~m}^{3} / \mathrm{s}$ and linear springs with flow rates that reach a total of approximately $5.0 \mathrm{~m}^{3} / \mathrm{s}$. These aquifers are of great importance as drinking water supply for a very large area of central Italy because of their great potential and water quality. The complex structural framework and the lithostratigraphic characteristics of the carbonate sequence make identifying both the hydrogeological boundaries and the hydraulic relationships among aquifers very difficult. The reason is mainly attributable to the actual displacements of the faults and to the definition of the dislocation extent of the overthrusts that are often overlapped, with local doubling in the hydrostratigraphic sequence, and often displaced by normal Apennine and transtensional faults that facilitate the hydraulic contacts among the aquifers of geological succession. Additionally, the different thicknesses of the (sometimes absent) Jurassic sequence are considered, leading to hydraulic 


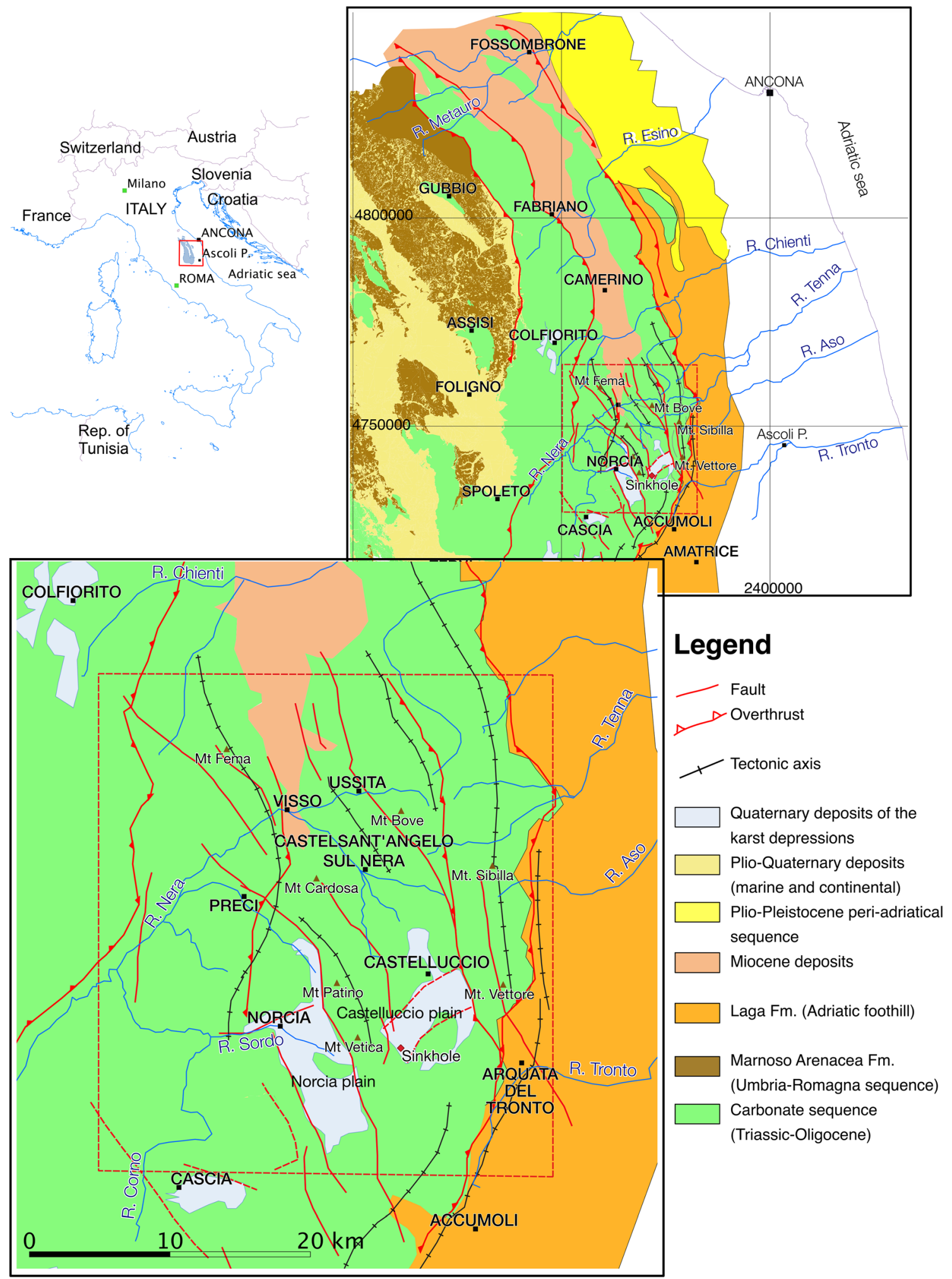

Fig. 1 Location of the study area. Geological scheme of the Umbria-Marche Apennine with tectonic features, modified after Barchi et al. (2012)

contact between the different carbonate aquifers in some areas.

This set of the aforementioned factors, unique to the Umbria-Marche carbonate ridges and more generally the
Apennine, is responsible for the mixing of water masses belonging to aquifers with different recharge elevations, as shown in previous works (Tazioli et al. 1990; Nanni and Vivalda 2005; Aquilanti et al. 2016). 
Tazioli et al. (2016), using tracer tests in areas with similar geo-structural and hydrogeological features, revealed hydraulic contacts of tectonic origin among carbonate aquifers of the same or different hydro-structures, which are separated from each other by overthrusts. Springs emerging from specific hydro-structures can be recharged by aquifers of adjacent hydro-structures, and the presence of normal or transtensional faults, which unblock overthrusts, can favour hydraulic continuity.

Further studies (Nanni and Rusi 2001; Nanni et al. 2006, 2013) conducted in other Apennine areas of central Italy indicated that, although emerging from different lithotypes, the springs are all fed by a powerful basal aquifer, with important contributions likely from the different carbonate aquifers, which are very large and are placed at different elevations. Other older studies (Lippi Boncambi 1950) hypothesised the existence of hydraulic connections between hydro-structures; however, these studies were published with a lack of reliable results, probably due to the analytical instrumentation available at the time.

Given these considerations and the detailed results acquired in previous studies, the present work aims to demonstrate the possible existence of a single large basal aquifer in the Sibillini Mountains, presumably subdivided into different structural sectors (Boni 2010), connected by hydraulic contacts of tectonic origin.

For this purpose, specific tracer tests were carried out involving the injection of artificial tracers in the sinkhole of Mèrgani Creek, located in the karst-tectonic depression of the Castelluccio di Norcia plain (Fig. 1), which is active in the period between late autumn and late spring. Given the extension of the studied area and the complicated morphological and tectonic characteristics, tracers were a good option to both define the hydrodynamic behaviour of aquifers and investigate the presence of spring-fed karst channels because they have been successfully applied for such purposes where fissures and karst formation exist (Goldscheider et al. 2008; Ravbar et al. 2012; Mudarra et al. 2014; Qi et al. 2018).

The experimental phase was further complicated by the occurrence of seismic events that affected some regions of central Italy in 2016/2017. During these events, the main shocks of which occurred in August 2016, October 2016 and January 2017, a strong increase in the flow rates of all the springs and linear springs fed by the Sibillini aquifers was immediately recorded; after some time, there was a drastic flow rate decrease in the springs emerging in the eastern and south-eastern Adriatic area, which in some cases, led to the disappearance of some high-elevation springs fed by the Maiolica and Scaglia aquifers (Petitta et al. 2018).

The preliminary results obtained in this work offer a fundamental contribution to a better understanding of the complex groundwater circulation in the Sibillini area; further tests will outline and confirm the current hydrogeological model.

\section{Framework of the Sibillini Mountains}

\section{Stratigraphic framework}

The oldest formation outcropping in the Sibillini area is the Calcare Massiccio (Upper Triassic-Lower Jurassic), composed of platform limestones approximately $700 \mathrm{~m}$ thick (Fig. 2a). In the Lower Jurassic, following extensional tectonics, the carbonate platform is disarticulated in different domains, separated by transtensional oblique and transversal fault systems (Boccaletti et al. 2005; Centamore et al. 2009; Carminati and Doglioni 2012), which give rise to horst and graben where sediments of complete, condensed and lacunose Jurassic formations are deposited.

The deposition of the complete sequence (Lower JurassicUpper Jurassic) occurred in the deepest sectors (graben) above the Calcare Massiccio Formation (Fm.) and is observed in the limestones and marls of the Corniola Fm. (thickness of $200 \mathrm{~m}$ ), Marne of Mount (Mt.) Serrone Fm. (thickness up to $150 \mathrm{~m}$ ), Rosso Ammonitico Fm. (thickness of approximately $40 \mathrm{~m}$ ), Calcari a Posidonia Fm. (up to $200 \mathrm{~m}$ thick) and Calcari Diasprini Fm. (up to $150 \mathrm{~m}$ thick). The Bugarone Fm., with a thickness of approximately $40 \mathrm{~m}$, is found in the structural high above the Calcare Massiccio Fm.

At the end of the Jurassic period, sedimentation formed the limestone of the Maiolica Fm. (thicknesses from 150 to $450 \mathrm{~m}$ ), the marls of the Marne a Fucoidi Fm. (50-80 m thick), the limestone, marly limestone and marls of the Scaglia Fm. (thicknesses up to $540 \mathrm{~m}$ ), the Scaglia Variegata Fm. (50 m thick), the Scaglia Cinerea Fm. (200 m thick), the Bisciaro Fm. (from 50 to $150 \mathrm{~m}$ thick) and the Schlier Fm. (from 80 to $200 \mathrm{~m}$ thick). A powerful succession consisting of siliciclastic turbiditic deposits followed. The overall thickness of the carbonate sequence above the Calcare Massiccio Fm. varies due to the presence of complete or condensed Jurassic sequences, reaching a maximum of 1,900 $\mathrm{m}$ (Centamore and Micarelli 1991; Pierantoni et al. 2013; Fig. 2a). Finally, in several wide areas of the mountain massif, continental Quaternary deposits (river and torrential alluvial deposits, lacustrine, glacial and slope deposits) are present.

\section{Geo-structural framework}

In general, the Umbria-Marche carbonate Apennine consist of two main structural units bordered by regional overthrusts: the Umbria-Marche ridge (inner ridge) and the Marche ridge (outer ridge), separated by the tectonic depression of AcqualagnaVisso, where Miocene deposits outcrop and form synclinal and anticlinal folds and where isolated minor carbonate ridges emerge (Deiana and Pialli 1994; Mazzoli et al. 2005; Mirabella et al. 2008; Scisciani 2009; Barchi et al. 2012; Pace et al. 2014). 
Fig. 2 a Stratigraphic and $\mathbf{b}$ hydrostratigraphic columns of the Umbria-Marche sequence a) Umbria-Marche ridge
litho-stratigraphic
sequence

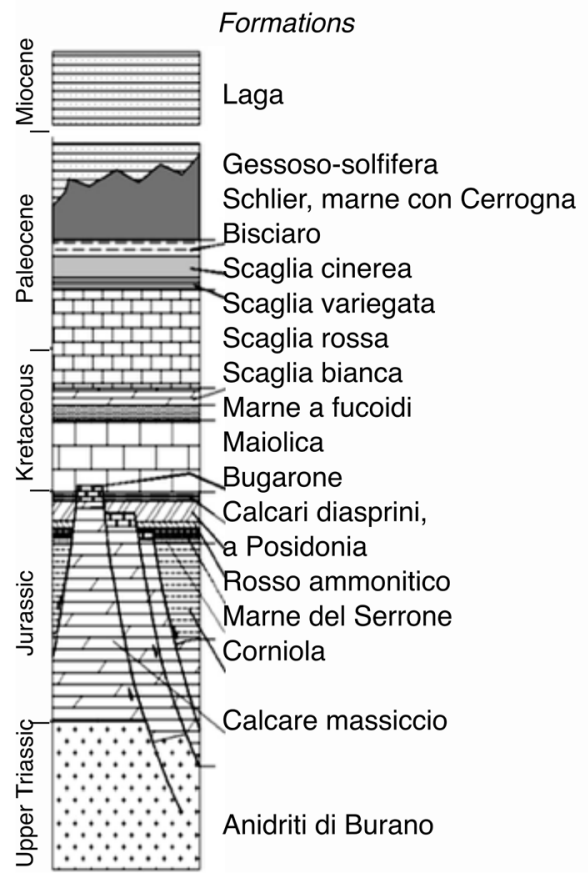

b) Umbria-Marche ridge hydrogeological sequence

Hydrogeological complexes

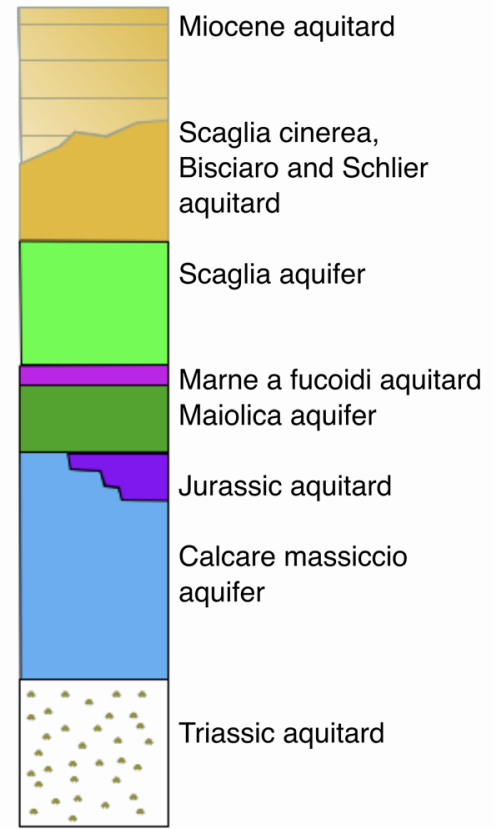

The geo-structural framework of the carbonate ridges is therefore characterised by arched overthrusts and antiform and synform folds with an ENE tilt (Bally et al. 1986; Barchi et al. 2012; Carminati and Doglioni 2012). On the western slope of the Mt. Sibillini range, the tectonic depression of Santa Scolastica is the boundary; on the Adriatic side, the tectonic boundary is the Olevano-Antrodoco-Sibillini overthrust of regional extension, for simplicity called the "Mt Sibillini overthrust" (Lavecchia 1985; Calamita et al. 2012; Pierantoni et al. 2013; Fig. 1). The main overthrust line is continuous and appears from south to north, with secondary planes that border minor tectonic elements where the main springs generally emerge (Fig. 1).

This important structural element limits and defines the mountainous side of the Apennine chain and marks the boundary between the carbonate ridge and the Mio-Pliocene terrigenous deposits of the Adriatic Pede-Apennine area (Adriatic foredeep; Calamita et al. 1994; Mazzoli et al. 2005; Di Domenica et al. 2012; Pierantoni et al. 2013). The overthrust forces the overlap of carbonate deposits on turbidite silico-clastic deposits of the Laga Fm. in the area south of the Aso River and on the Scaglia Cinerea, Bisciaro and Schlier Fms. in the northern area. The extent of the displacement was estimated to be approximately $10 \mathrm{~km}$ (Mazzoli et al. 2005).

The dominant structure over the Sibillini area is given by an association of folds, overthrust, and faults. The Neogene compressive structures are also dislocated by extensive Quaternary faults showing "belts" with a N140-150 trend and lowering to WSW (Mazzoli et al. 2005; Scisciani 2009). These faults, sometimes with indications of recent activity (Mazzoli et al. 2005; Di Domenica et al. 2012), as in the 2016 earthquake that hit central Italy, have a main NNWSSE direction (Aringoli et al. 2018).

The Quaternary faults are responsible for the characteristic morpho-structural setting of the Sibillini Mountains and limit three structural sectors, with blocks lowering and forming steps from the Adriatic side of the overthrust to the Santa Scolastica plain in Norcia to the west. More specifically, the eastern sector is included between the overthrust and the normal faults bordering the Mt. Bove-Mt. Vettore system, with a total displacement of hundreds of metres. In this sector, the highest elevations of the Sibillini Mountains are present (Mt. Vettore, 2,476 m), and the deepest aquifer extensively outcrops.

The western sector, with elevations below 2,000 $\mathrm{m}$ above sea level (asl), is bordered on the east by extensional faults and on the west by the normal fault that borders the Santa Scolastica plain with an estimated displacement of 1,000 m. The central sector, with the tectonic-karstic depression of the Castelluccio di Norcia plain (approximately 1,300 m asl), is bordered by normal faults with displacement over $500 \mathrm{~m}$ (Fig. 1). The different structural sectors with folds are dipping approximately to the NW towards the Nera River and are released by transpressional N-S and E-W faults, which also displace the overthrusts.

In short, the structural setting of the area is characterised by an axial immersion of the folds towards the NW, which 
caused the outcropping of the Calcare Massiccio and Maiolica Fms. at high elevation in the eastern and southern areas (Mt. Vettore and Mt. Bove). In the northern area, in contrast, these deposits emerge near the thalweg of the Nera River at elevations between 600 and $900 \mathrm{~m}$ asl and border the Santa Scolastica plain on the western side (Fig. 1).

\section{The tectonic-karst depressions of Castelluccio di Norcia and Santa Scolastica}

The karst phenomenon in the Sibillini area is generally not well known, mostly due to a lack of karst systems that can be thoroughly inspected. Shallow karst forms are, however, known and associated with the Calcare Massiccio Fm. outcropping at Mt. Sibilla (Giovagnotti 1975; Coltorti and Farabollini 1995), at Mt. Bove and Cima Pretare (Mt. Vettore massif). In this formation there are minor karst forms such as karren, rillenkarren, kamenitza and solution holes (Coltorti and Farabollini 1995); in the Scaglia Fm. there are shapes similar to dolines.

The depression of the Castelluccio di Norcia plain is significant evidence of the presence of karst in the Sibillini carbonate rocks and a peculiar morphological element of the area. It is a closed Apenninic wide depression, formed after the Quaternary extensional tectonics. The eastern edge of the plain is bordered by the scarp of the Mt. Vettore group and by the major reliefs of the Umbria-Marche Apennine chain (Fig. 1). The western edge, where the sinkhole of the Mèrgani creek is located in the southern part, is aligned with a fault at the base of Mt. Castello and is delimited by reliefs at lower elevations.

In the plain, there are morphological forms similar to dolines, and deposits and karstic forms are likely present in the carbonate substratum, masked by the thick fluvial-lacustrine deposits (up to $400 \mathrm{~m}$ ), which have filled the ancient subsiding basin.

On the western side, the Mt. Sibillini are actually bounded by the tectonic depression of Santa Scolastica (approximately $650 \mathrm{~m}$ asl), bordered to the east and west by extensive Quaternary faults with many signs of recent activity (Calamita et al. 1982; Pizzi and Scisciani 2000). Slope debris deposits, alluvial fan deposits, alluvial and fluvial-lacustrine deposits filled the depression with thicknesses of several tens of metres. It is likely that this plain was also affected by karst phenomena in the past (Coltorti and Farabollini 1995).

\section{Hydrogeological framework of the Sibillini Mountains}

\section{Aquifers and boundaries of the hydrogeological domain}

The Sibillini Mountains are one of the most studied areas of the Umbria-Marche carbonate ridges (Lippi Boncambi 1950;
Giovagnotti 1975; Boni et al. 1986; Mastrorillo and Baldoni 2009; Boni 2010; Mastrorillo and Petitta 2014). Many authors indicated the presence of numerous hydrogeological structures not hydraulically connected to one another and provided basic knowledge on the hydrogeology of the area. Nanni and Rusi (2001) and Nanni et al. (2006) studied the hydrodynamics of aquifers that feed the main springs emerging on the Adriatic side of the Sibillini: the springs are recharged by aquifers with a rather fast water circulation conditioned by fissures and karst, which plays an important role in the recharge and in the groundwater circulation in the aquifers (Fig. 2b).

Due to the intense fissuration of the carbonate lithotypes and the karstic phenomena, the infiltration of meteoric water is at least as high and fast as the water circulation in the aquifers; the shape of the hydrographs of the main springs on the Adriatic side (Nanni et al. 2006) highlights this phenomenon. Other studies (Nanni et al. 2006, 2013; Tarragoni 2006) identified the recharge areas of some important springs of the Sibillini, emerging near the overthrust front (Pescara, Capodacqua and Foce springs) of approximately 1,340 $1,420 \mathrm{~m}$ asl.

In the Sibillini massif, as in the rest of the Umbria-Marche carbonate Apennine, the hydrogeological complexes of the Calcare Massiccio, Maiolica and Scaglia are present (Boni et al. 1986; Caprari and Nanni 1999; Nanni and Vivalda 2005), featuring a geo-structural complexity due to the extensional tectonics, which, together with the variability in the stratigraphy of the Jurassic sequence, makes the identification of the hydrogeological boundaries of the aquifers very difficult and leaves their hydraulic relationship undefined (Figs. $2 b$ and 3 ).

On the other hand, based on the available knowledge of the geo-structural setting, the boundaries of the hydrogeological domain of the Sibillini massif can be outlined in broad terms (Pierantoni et al. 2013). In particular, in the southern and eastern areas, the hydrogeological limit is represented by the Mt. Sibillini overthrust (Fig. 1). The marls of Scaglia Cinerea, Bisciaro, Marne con Cerrogna and Schlier Fms. seal the complex developing on the Adriatic side the overall aquitard for carbonate aquifers (Fig. 4).

In the west, the boundary is represented by the NottoriaNorcia-Preci tectonic line dividing the Santa Scolastica plain, with a thick aquifer in the continental deposits (Biella et al. 1981), from the western slope of the massif. Finally, in the northern area, the Nera River, with its tributary Ussita Stream, is the main area of groundwater discharge, in accordance with the structural framework characterised by the immersion towards the NW of the folds' axes. However, this area cannot be defined as an actual hydrogeological limit; in fact, the geo-structural relationship between the Sibillini Mountains and some carbonate ridges farther north are reminiscent of some hydraulic contacts between them, especially in the Marche ridge (Boni et al. 1986; Petitta et al. 2018). 


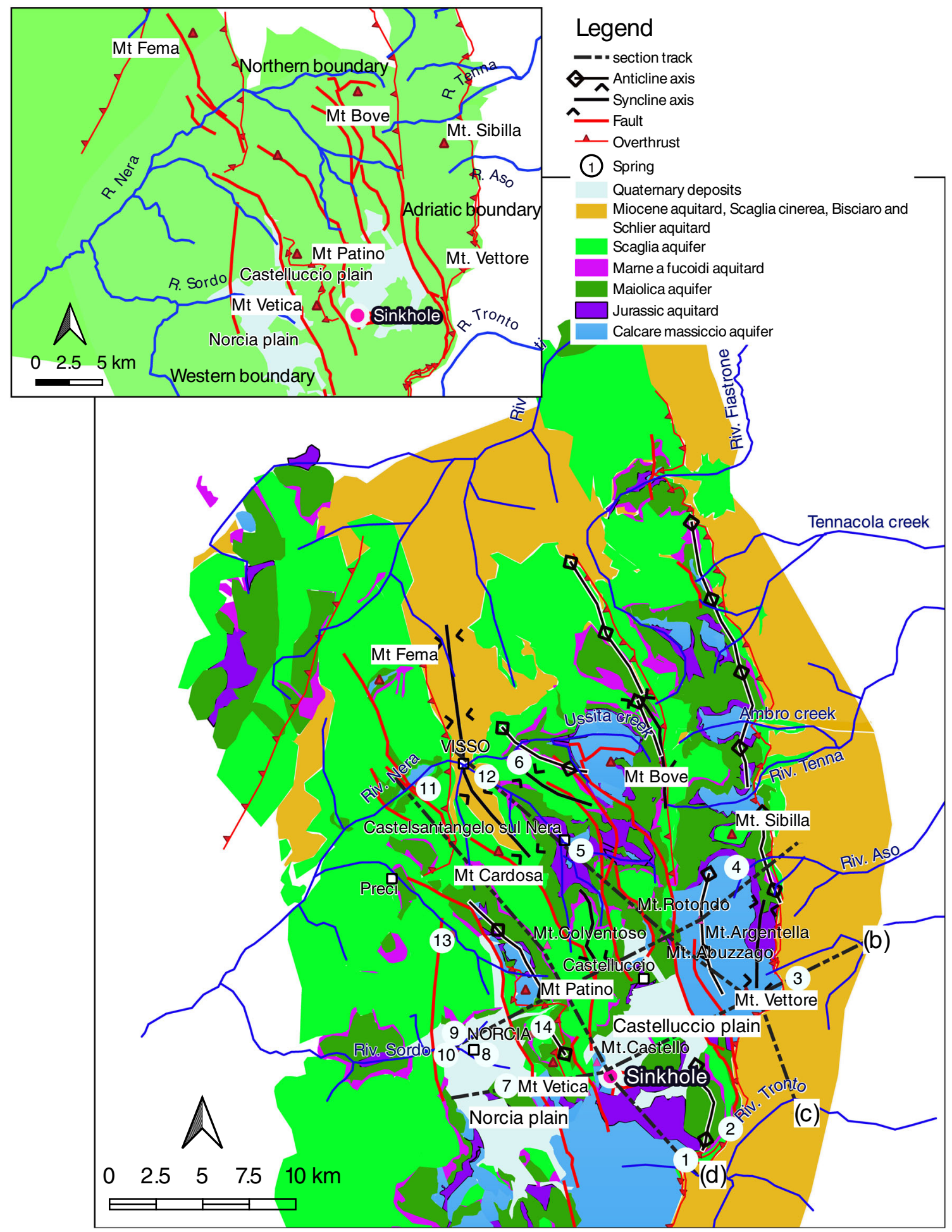

Fig. 3 Hydrogeological schematic map of the study area. Legend for the springs: 1 Capodacqua, 2 Pescara, 3 Sassospaccato, 4 Foce, 5 San Chiodo, 6 Ussita linear springs, 7 Torbidone, 8 San Martino, 9

\section{Springs on the Adriatic side}

Capodacqua, Pescara and Foce are the main springs on the Adriatic side, emerging near the overthrust front and
Salicone, 10 Sordo linear springs, 11 Nera linear springs (Pontenuovo), 12 Nera linear springs (Visso), 13 Campiano linear springs and 14 Capregna

recharged mostly by the Calcare Massiccio basal aquifer ((a) and (d) in Fig. 4). They exhibit a calcium bicarbonate chemistry with a low salt content, and only the Foce spring, emerging directly from the Calcare Massiccio Fm., shows a slight 
Fig. 4 Cross and longitudinal hydrogeological sections related to Fig. 3. The section tracks are indicated in the map in Fig. 3
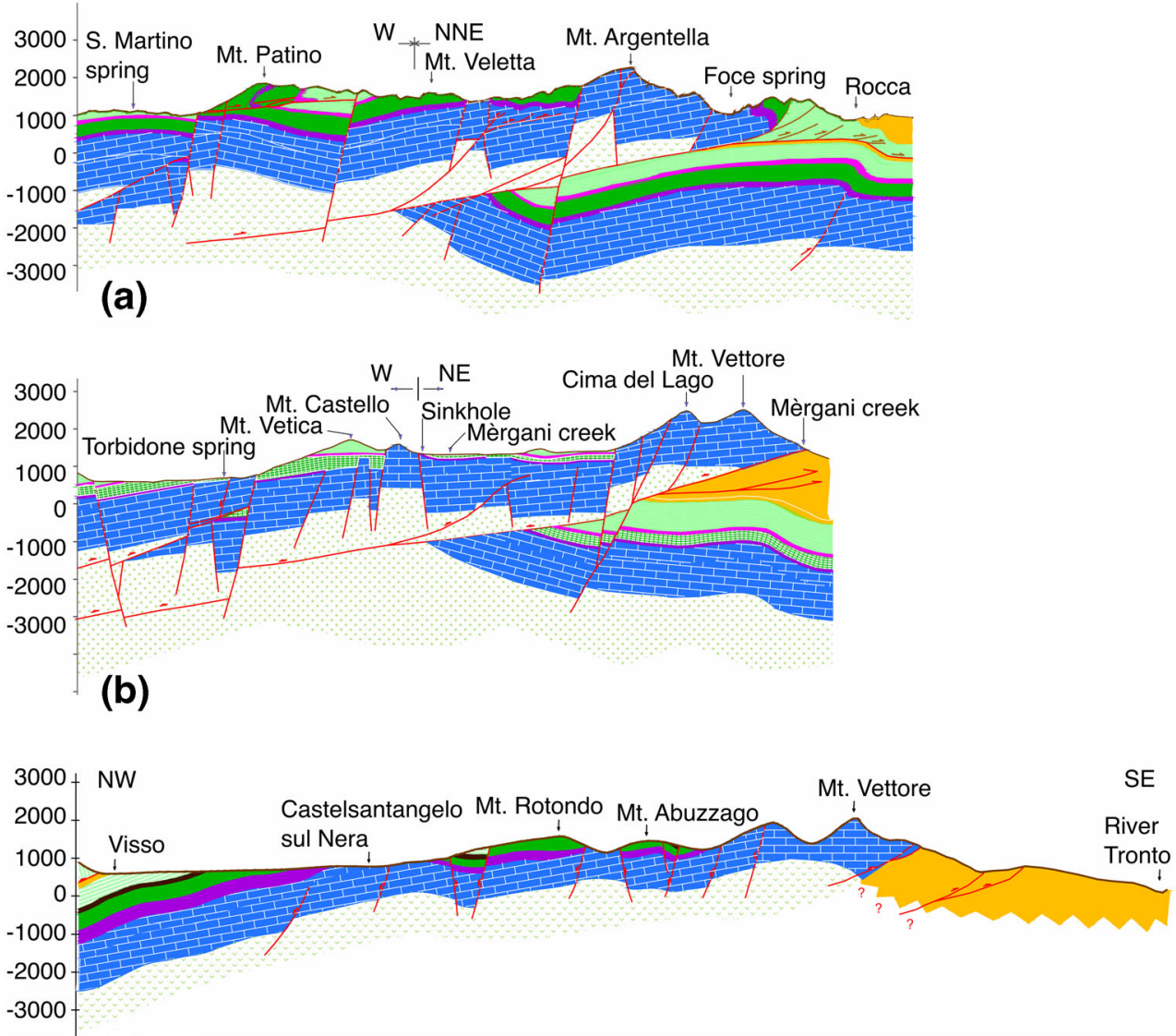

(c)

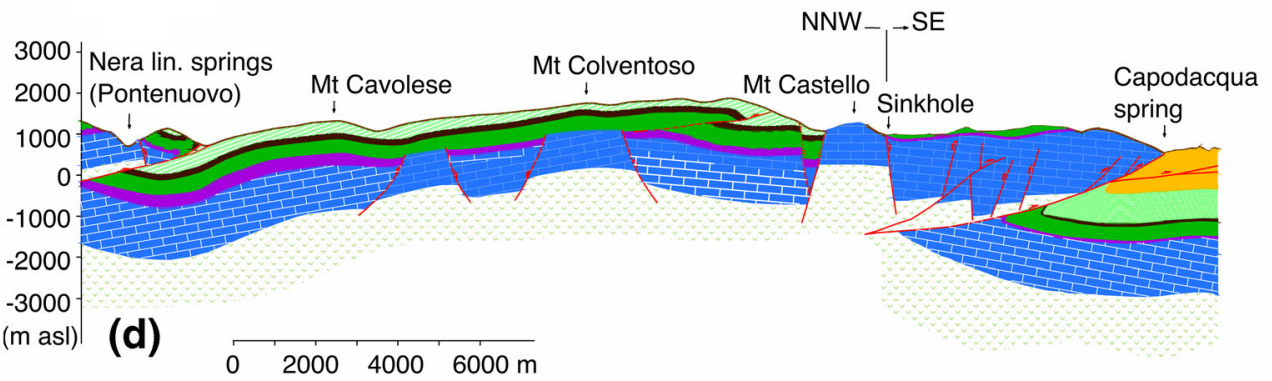

enrichment in sulphates. The electrical conductivity of the spring water varies between 250 and $300 \mu \mathrm{S} \mathrm{cm}^{-1}$. The temperature is rather constant over time: approximately $8.3^{\circ} \mathrm{C}$ for the Pescara and Capodacqua springs and $6.8^{\circ} \mathrm{C}$ for the Foce spring. The latter is the lowest value among the analysed springs with a small annual excursion (Table 1). In the emerging areas, via secondary slip surfaces, the lithotypes of the Maiolica and Scaglia Fms. are in tectonic contact with the Calcare Massiccio Fm., rarely outcropping in this zone. The springs show different mean discharges, generally with significant annual excursions, maximum values over $1.3 \mathrm{~m}^{3} \mathrm{~s}^{-1}$ and minimum values up to approximately $0.03 \mathrm{~m}^{3} \mathrm{~s}^{-1}$ (Pescara spring) in dry periods (Nanni et al. 2006). The Foce spring discharge, which is rather constant, is rarely less than $0.5 \mathrm{~m}^{3} \mathrm{~s}^{-1}$ (pre-earthquake values in 2016).
The constancy of the physicochemical parameters over the hydrological year indicates that the aquifers recharging the three springs are very extended, with high volumes of stored water to mitigate the seasonal thermal recharge signal; in addition, the low temperature and electrical conductivity can be associated with the thermometric values of the aquifer recharge waters, in part due to the snow melt. In fact, in the area, the snowpack is normally present at elevations of $1,000 \mathrm{~m}$ asl or above from late autumn to early spring. Analysis of the physicochemical parameters also demonstrates the rapid infiltration of rainwater and the high velocity of groundwater circulation, fostered by both the high fissuring of lithotypes and karstification (Boni et al. 1986; Caprari and Nanni 1999).

The springs and linear springs emerging in the eastern part of the Sibillini feed all the rivers of the Adriatic side that cross 
Table 1 Physico-chemical properties and flow rate of the monitored points. lin. linear

\begin{tabular}{|c|c|c|c|c|c|c|c|c|}
\hline \multirow[t]{2}{*}{ Parameter } & \multicolumn{8}{|c|}{ Sample sites } \\
\hline & $\begin{array}{l}\text { Torbidone } \\
\text { spring }\end{array}$ & $\begin{array}{l}\text { S.Martino } \\
\text { spring }\end{array}$ & $\begin{array}{l}\text { Sordo lin. } \\
\text { springs }\end{array}$ & $\begin{array}{l}\text { Foce } \\
\text { spring }\end{array}$ & $\begin{array}{l}\text { Pescara } \\
\text { spring }\end{array}$ & $\begin{array}{l}\text { Capodacqua } \\
\text { spring }\end{array}$ & $\begin{array}{l}\text { S.Chiodo } \\
\text { spring }\end{array}$ & $\begin{array}{l}\text { Nera lin. } \\
\text { springs }\end{array}$ \\
\hline Elevation (m asl) & 640 & 600 & 570 & 970 & 830 & 900 & 800 & 500 \\
\hline Temperature $\left({ }^{\circ} \mathrm{C}\right)$ & 10.2 & 11.1 & 12.4 & 6.8 & 8.3 & 8.4 & 8.3 & 9.2 \\
\hline $\begin{array}{l}\text { Electrical conductivity } \\
\qquad(\mu \mathrm{S} / \mathrm{cm})\end{array}$ & 490 & 560 & 550 & 260 & 250 & 300 & 320 & 335 \\
\hline $\mathrm{Ca}^{2+}$ & 70.5 & 86.4 & 83.2 & 36.5 & 48.6 & 47.6 & 49.4 & 62.1 \\
\hline $\mathrm{Mg}^{2+}$ & 12.4 & 16.5 & 13.9 & 8.3 & 3.0 & 6.1 & 6.8 & 4.0 \\
\hline $\mathrm{Na}^{+}$ & 2.3 & 3.5 & 3.2 & 1.5 & 2.7 & 2.4 & 1.6 & 3.6 \\
\hline $\mathrm{K}^{+}$ & 0.6 & 1.0 & 2.8 & 0.4 & 0.4 & 0.4 & 0.6 & 0.7 \\
\hline $\mathrm{HCO}_{3}^{-}$ & 207 & 217 & 231 & 140 & 165 & 189 & 156 & 192 \\
\hline $\mathrm{Cl}^{-}$ & 3.4 & 6.5 & 4.8 & 2.1 & 3.6 & 4.3 & 2.4 & 8.2 \\
\hline $\mathrm{SO}_{4}^{-}$ & 68.4 & 108.1 & 85.2 & 16.3 & 4.2 & 5.1 & 28.9 & 9.1 \\
\hline $\mathrm{NO}_{3}^{-}$ & 3.1 & 8.7 & 6.4 & 1.0 & 1.6 & 1.2 & 1.4 & 1.8 \\
\hline $\begin{array}{l}\text { Discharge range } \\
\quad(\min -\max )\end{array}$ & $0.71-1.63$ & $0.02-0.31$ & $0.61-2.21$ & $0.42-1.31$ & $0.03-0.56$ & $0.11-0.79$ & $0.45-0.73$ & $2.21-3.32$ \\
\hline
\end{tabular}

the carbonate ridge and are subjected to a strong flow increase due to groundwater coming from the main aquifers. These springs reach maximum flow rates of well above $5 \mathrm{~m}^{3} \mathrm{~s}^{-1}$.

\section{Springs on the western side}

Springs and linear springs emerge along the rivers and are located at the base of the slope on the western side of the Sibillini Mountains (Fig. 3). Some springs are near or at the border of the Santa Scolastica plain, where a thick continental aquifer is fed by both local rainwater and groundwater coming from the carbonate aquifers surrounding the plain (Fig. 4a,b). A peculiarity is the karst spring of the Torbidone River, which disappeared following the earthquake of 1979 and reappeared after the seismic events of October 2016, with an initial flow of over $1.6 \mathrm{~m}^{3} \mathrm{~s}^{-1}$ (Valigi et al. 2019). The spring rises with a series of openings on the earth surface due to karstic activity. The linear springs of the Sordo River, also located in the Santa Scolastica plain, had a flow rate of approximately $0.7 \mathrm{~m}^{3} \mathrm{~s}^{-1}$ before the reappearance of the aforementioned spring; after the seismic events, its discharge increased to over $2.1 \mathrm{~m}^{3} \mathrm{~s}^{-1}$ (Petitta et al. 2018). Other springs in the plain have more limited flows (Salicone and San Martino springs). In general, all the springs of the western side show a chemistry characterized by higher salinity and temperature with higher content of magnesium and sulphates with respect to the Adriatic side springs (Table 1).

\section{Springs on the northern side}

The main springs emerging close to the northern hydrogeological boundary of the Sibillini Mountains, mainly recharged by the basal aquifer, are the linear springs of the Nera River (Visso and Pontenuovo, with average estimated overall flow rates of over $2.5 \mathrm{~m}^{3} \mathrm{~s}^{-1}$ ), the Ussita creek (flow rates of approximately $0.7 \mathrm{~m}^{3} \mathrm{~s}^{-1}$ ) and the San Chiodo spring (Castelsantangelo sul Nera area) with a discharge up to $0.7 \mathrm{~m}^{3} \mathrm{~s}^{-1}$ (Figs. 1, 3, and $4 a, c)$.

Significant variations were noted in the springs and rivers of the northern area following the 2016 seismic event - for example, the Nera River flow has increased more than $9 \mathrm{~m}^{3}$ $\mathrm{s}^{-1}$ towards the closing section, immediately after the seismic shock; for the springs of the Nera River, an increase of over 2 $\mathrm{m}^{3} \mathrm{~s}^{-1}$ was recorded (Petitta et al. 2018). Chemistry is similar to Adriatic side springs, especially the Pescara and Capodacqua springs, with slight enrichment in some elements; sulphate concentrations are higher (Table 1).

\section{Materials and methods}

The experimental tests were conducted with different detection methods chosen to enable selection of both the most suitable tracer and the optimal measurement for the study area, which, being very extended, required very long investigation times. Tinopal CBS-X (Colorey, France; molecular formula $\mathrm{C}_{28} \mathrm{H}_{20} \mathrm{Na}_{2} \mathrm{O}_{6} \mathrm{~S}_{2}$ ) and sodium fluorescein (Colorey, France; molecular formula $\mathrm{C}_{20} \mathrm{H}_{10} \mathrm{Na}_{2} \mathrm{O}_{5}$ ) were used as tracers; both are widely used in hydrogeological applications on a large or small scale (Uggeri and Vigna 1990; Goldscheider et al. 2008; Ravbar et al. 2012; Lauber and Goldscheider 2014; Mudarra et al. 2014; Qi et al. 2018; Tazioli et al. 2019). 
First, to determine the duration, sampling frequency and other characteristics of the definitive tracer tests, a qualitative pilot test was carried out using fluorescent traps filled with activated carbon (Aquilanti et al. 2013) to determine the tracer concentration in the extracts. Second, three quantitative tracer tests were performed in the study area (Fig. 4): traps were used as "backup", spot samples were taken during the tests, and automatic samplers were used to collect samples at set time intervals. Finally, fluorometric probes, which continuously measured and recorded the tracer concentration for the duration of the tests, were installed in the field.

The samples and the fluorescent trap extracts were analysed in the laboratory using a Shimadzu RF6000 spectrofluorometer. Standards of different concentrations were prepared with water from the monitored sites.

The fluorescent probes were produced by Albillia Co. (Switzerland) and PME Inc. (USA) and contained various optics for tracer detection and a power supply and data logger for storing the measured data. These probes are designed to remain in the field for a long time and thus ensure continuous and frequent data acquisition. The data acquisition intervals were set at 5 and $15 \mathrm{~min}$ during the various tests.

The tests were made possible by the presence of the karst sinkhole in the most topographically depressed part of the Castelluccio plain, likely connected with the hydrogeological system that feeds most of the springs of the Sibillini Mountains. The distance between the entry point and the various springs ranges from a minimum of $6 \mathrm{~km}$ to a maximum of approximately $19 \mathrm{~km}$.

Two tracer tests were performed in the period prior to the seismic event in August 2016: the first involved the instantaneous introduction of $2 \mathrm{~kg}$ of sodium fluorescein into the karst sinkhole (February 2016) with monitoring for approximately 3 months, and the second involved the injection of $29 \mathrm{~kg}$ of Tinopal CBS-X and monitoring for approximately 5 months starting in June 2016. A third test was finally performed after the seismic events and involved the injection of approximately $85 \mathrm{~kg}$ of Tinopal CBS-X starting in March 2017 and lasting approximately 1 year.

In addition, some weather stations were chosen in the studied area with the aim of covering the entire investigated area and have reliable data of the precipitation input (rainfall and snow) in the Mt. Sibillini, at elevations between $600 \mathrm{~m}$ and $1,950 \mathrm{~m}$ asl (Fig. 5). The Thiessen method was used to achieve average rainfall data for the investigated period.

\section{Results}

The results obtained from the tracer tests, described in the following, are arranged according the monitoring points of the selected springs emerging near the hydrogeological boundaries (eastern, western and northern side of the Sibillini complex). Tracer results are presented in the form of breakthrough curves (BTCs), i.e., tracer concentration vs. time.

\section{Springs of the eastern hydrogeological boundary in the Adriatic side}

Capodacqua spring In this spring (located at $5.5 \mathrm{~km}$ from the sinkhole), the tracer is recovered rather quickly during both the recharge and recession periods, with several repeated peaks. In the first test (Fig. 6), fluorescein arrives after 14 days in a period corresponding to the final part of the rising limb of the hydrograph, with a pulse-type pattern and high tracer concentrations and disappearing after approximately 2 months. In the second test, Tinopal arrives after 17 days, agreeing with the initial stretch of the recession limb and involving two series of pulses, and then disappears approximately 20 days before the arrival of the seismic shock, which induces an initial sudden increase and then a decrease in flow rates after the second seismic shock. In the third test, after the second seismic shock and in the recession period of the spring with a discharge (approximately $0.33 \mathrm{~m}^{3} \mathrm{~s}^{-1}$ ) about $0.2 \mathrm{~m}^{3} \mathrm{~s}^{-1}$ lower than that in the previous tests, the tracer arrives with a pulsetype pattern after only 5 months (167 days); the BTC exhibits a single marked peak related to a series of pulses lasting approximately $72 \mathrm{~h}$.

Pescara spring This spring is located approximately $6.9 \mathrm{~km}$ from the Mèrgani sinkhole. Before the earthquake of August 2016, the tracer arrived quickly (13 days) with several peaks every 3-4 days (Fig. 7) and disappeared after approximately 1 month. The arrival of the tracer was recorded in connection with the maximum flow rates of the spring (about $0.35 \mathrm{~m}^{3} \mathrm{~s}^{-1}$ ). The earthquake of 2016 initially caused an instantaneous increase in the spring flow (from 0.3 to $0.42 \mathrm{~m}^{3} \mathrm{~s}^{-1}$ ), followed by a continuous decrease to $0.05 \mathrm{~m}^{3} \mathrm{~s}^{-1}$ in 2017. The arrival curve is pulse-like. After the earthquake, the tracer was not recovered.

Foce spring This spring is located $13 \mathrm{~km}$ from the sinkhole and showed a total average discharge of approximately $0.6 \mathrm{~m}^{3} \mathrm{~s}^{-1}$ before the earthquake. There was no evidence of the tracer before the seismic sequence; the tracer reached the spring for the first time 45 days after the seismic event of August 2016 and after approximately 255 days from entering the sinkhole; the curve has a pulse character. In the second test, the tracer reaches the spring in the months of July and August 2017, approximately 1 year after being injected. Later arrivals probably related to the third test and repeated in three distinct phases, all taking place during the recession limb of the hydrograph; these arrivals are extremely prolonged following the seismic event but are always in correspondence 
Fig. 5 Location of the monitoring points of the tracer tests. Red stars with red numbers are the fluorometer probes: 1

Capodacqua spring, 2 Pescara spring, 3 Torbidone spring, 4 Sordo linear springs, 5 Foce spring, 6 San Chiodo spring, and 7 Nera linear springs

(Pontenuovo). Fluorescent traps are represented by black circles: 1 Capodacqua spring, 2 Pescara spring, 3 Torbidone spring, 4 San Martino spring, 5 Sordo linear springs, 6 Foce spring, 7 San Chiodo spring, 8 Nera linear springs (Visso), 9 Ussita linear springs, 10 Nera linear springs (Pontenuovo), 11 Campiano creek (Preci), 12 Tenna River, 13 Ambro Creek, 14 Fiastrone River. 15 Tennacola River and 16 Campiano linear springs

Fig. 6 Tracer breakthrough curves for the Capodacqua spring
Legend

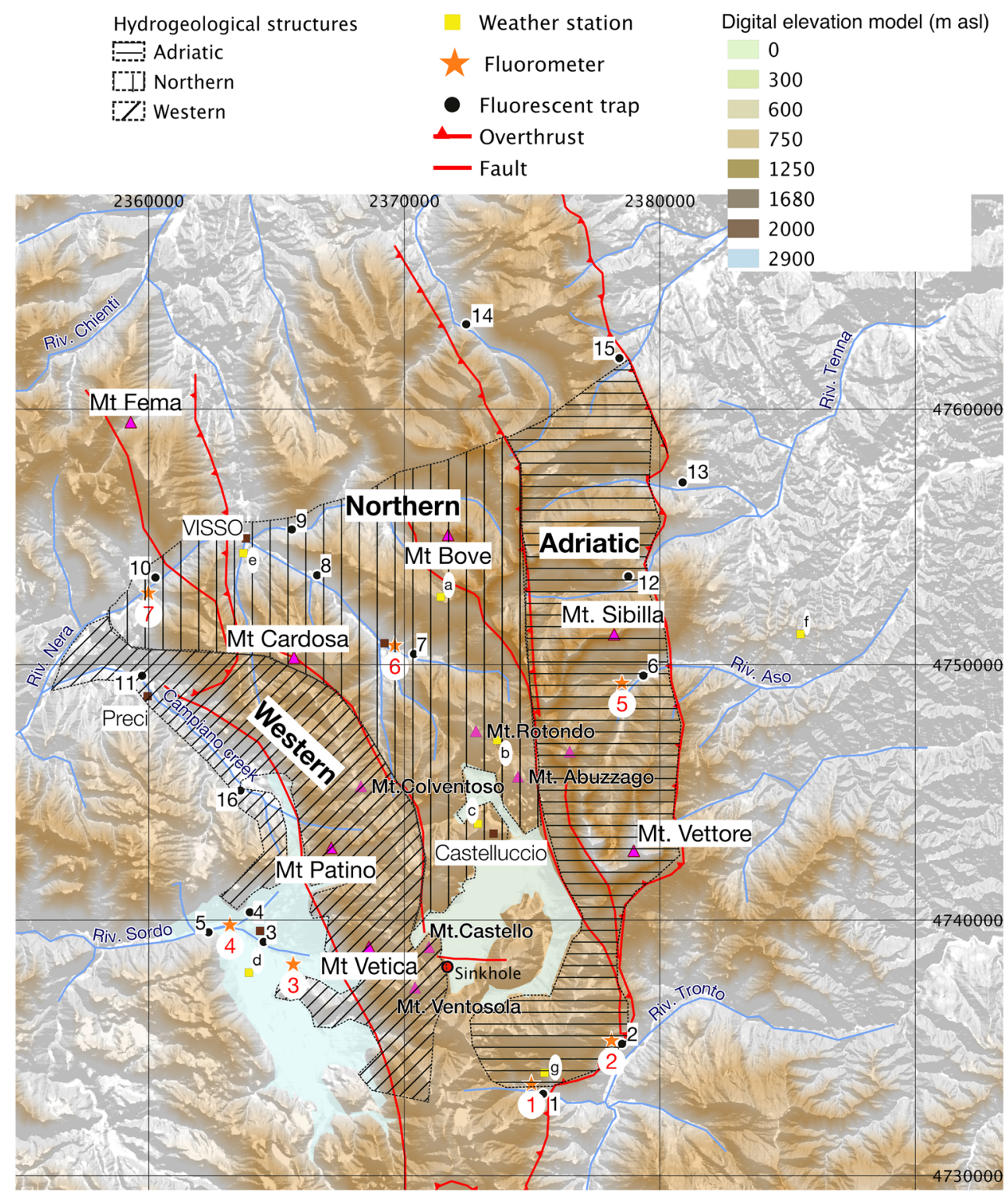


Fig. 7 Tracer breakthrough curves for the Pescara spring

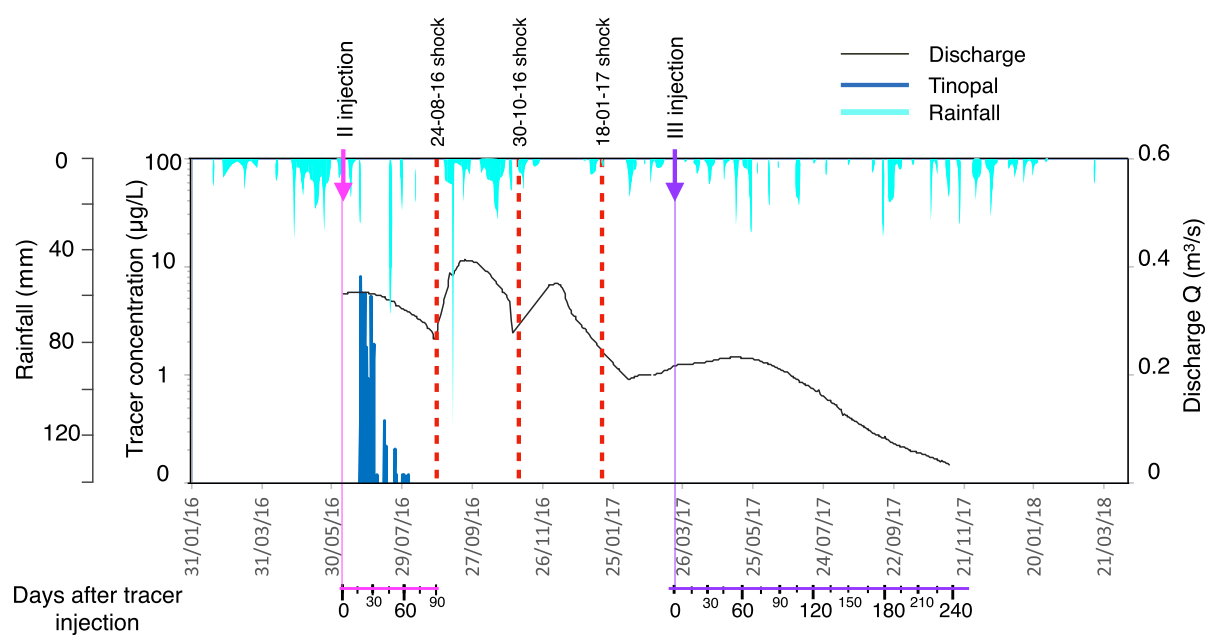

with local increases in flow (Fig. 8). Analysis of fluorescent traps confirmed the arrivals, although characterized by low values.

\section{Springs on the western side (Santa Scolastica plain, western hydrogeological boundary)}

Sordo linear springs and Torbidone spring In the linear springs of the Sordo River, emerging in the "Marcite of Norcia" ( $8.5 \mathrm{~km}$ away from the sinkhole), the tracer of the second test arrived only 1 week after the first seismic quake (approximately 3 months after the tracer injection), when the river discharge was approximately $1.65 \mathrm{~m}^{3} \mathrm{~s}^{-1}$ (Fig. 9). The arrival curve was hydro-dispersive, and the tracer completely disappeared in approximately 20 days. There was no evidence of tracer arrival at the Sordo linear spring during the first test and at the Torbidone spring during the third test.

San Martino spring In contrast, the San Martino spring (7.2 km away from the swallow hole), which was sampled periodically and manually, was in contact with the aquifer to which the Castelluccio plain also belongs, as highlighted in the second test. The tracer of the second test, in fact, arrived 8 days after the injection (eight samples showed in fact concentration values well above the detection limit).

\section{Springs on the northern side (northern hydrogeological boundary of the Sibillini Mountains)}

San Chiodo spring The San Chiodo spring emerges along the Nera River Valley, the northern boundary of the karst plain of Castelluccio and $12.6 \mathrm{~km}$ away from the sinkhole, and directly feeds the Nera River. The tracer was detected with a similar BTC (pulse pattern) both before and after the earthquake.

In the first test, the fluorescein reached the spring after 19 days and disappeared after approximately 1 month, during the rising limb of the river hydrograph, when the discharge was approximately $0.8-0.9 \mathrm{~m}^{3} \mathrm{~s}^{-1}$ (Fig. 10). After the earthquake, the Nera River flow considerably increased by $400 \%$ in few months. In the third test, which was performed during the recession limb of the river hydrograph, the Tinopal arrived 28 days after its introduction, with close pulses and high concentrations (until $20 \mathrm{ppb}$ ), and this arrival pattern was repeated continuously for a period of approximately 4 months. The

Fig. 8 Tracer breakthrough curves for the Foce spring

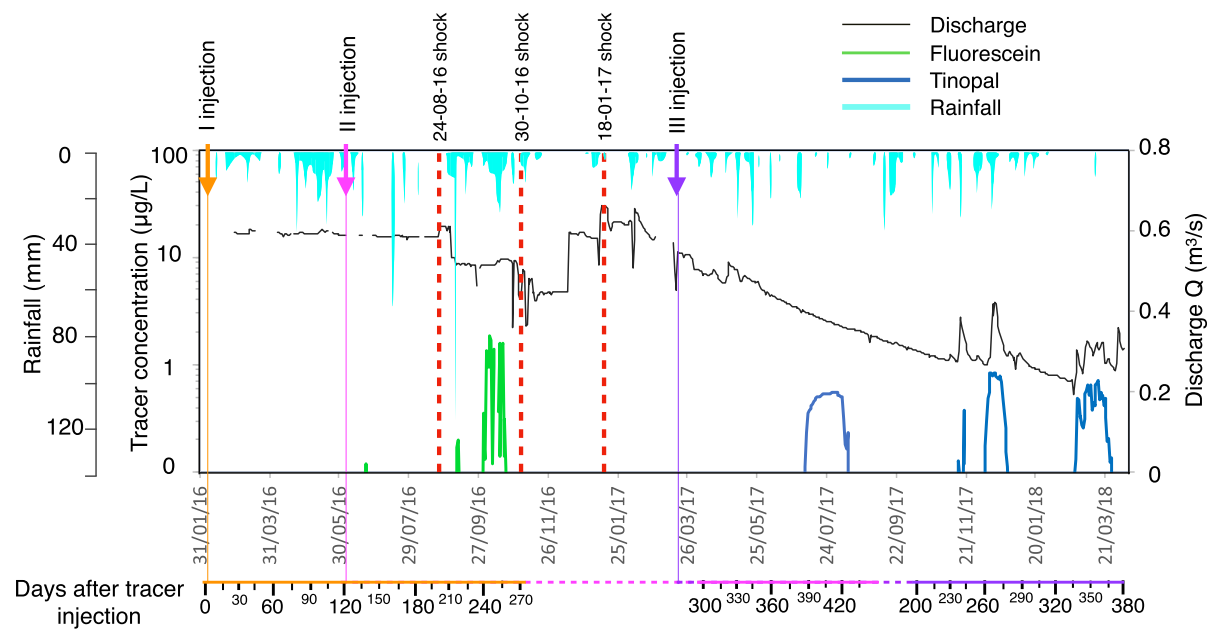


Fig. 9 Tracer breakthrough curves for the springs of the Norcia plain (western sector)

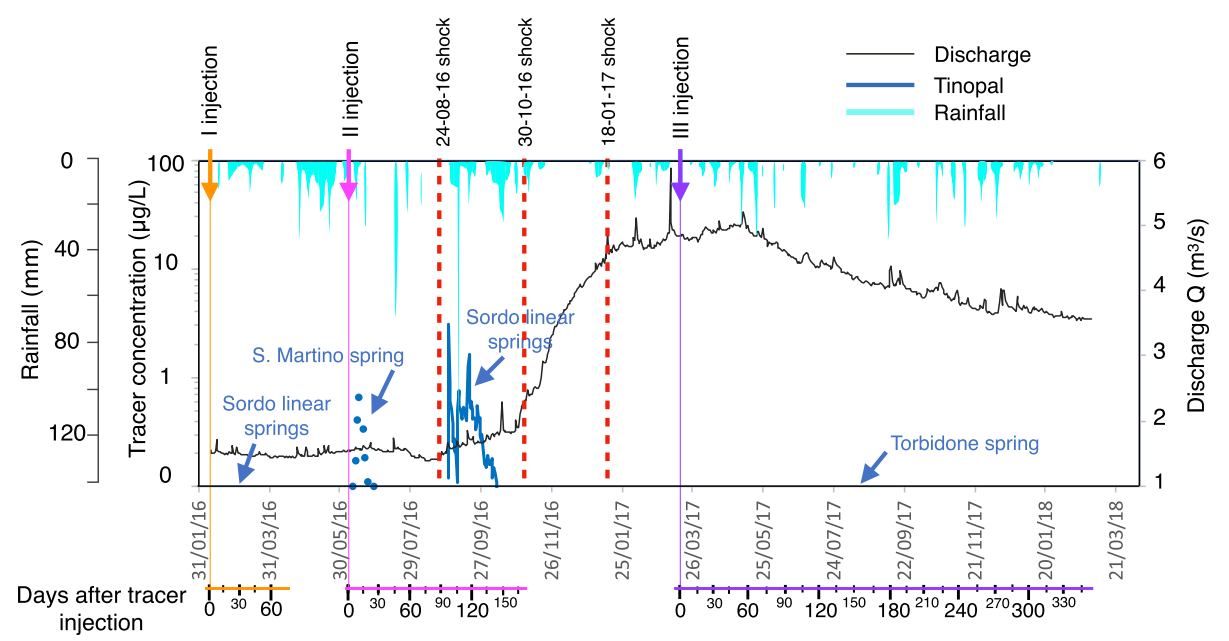

final disappearance of the tracer was recorded after an additional 3 months.

The Nera linear springs (Pontenuovo) Approximately $10 \mathrm{~km}$ downstream of the St. Chiodo spring, some linear springs recharge the Nera River in the outcropping zone of the Calcare Massiccio Fm., near the small village of Pontenuovo, approximately $19 \mathrm{~km}$ from the swallow hole. During the first test, the tracer was detected (through periodic manual sampling) 26 days after its injection, and its arrival lasted approximately 15 days during the rising phase of the Nera River hydrograph. The Tinopal that entered during the second test (during the recession limb of the discharge curve) was detected only after the first earthquake, probably as a result of a sudden increase in river discharge (about $0.3 \mathrm{~m}^{3} \mathrm{~s}^{-1}$ ), approximately 130 days after its release but only 6 days after the earthquake of August 2016, which caused a modest instantaneous increase in the level of the Nera River. Both curves show a hint of dispersion, with some peaks (Fig. 11).
In the last test, the arrival of the tracer occurred with different peaks separated from one another over long time intervals. The first arrival occurred during the recession period, approximately 4 months after the release, and the arrivals of the successive peaks coincided with modest increases in flow and were recorded for a total period of approximately 7 months.

\section{Discussion of results}

The seismic crisis that struck central Italy in 2016-2017 (Chiaraluce et al. 2017; Luzi et al. 2017) strongly altered the conditions of the Sibillini aquifer and changed the flow rates of springs and streams, as highlighted by the study of Petitta et al. (2018), and the hydraulic relationships between the hydrogeological complexes were modified, likely due to the reactivation of various structural features. The detailed amount of such changes was difficult to evaluate without further tests, due to both several factors that complicate the
Fig. 10 Breakthrough curves of the tracer for the San Chiodo spring

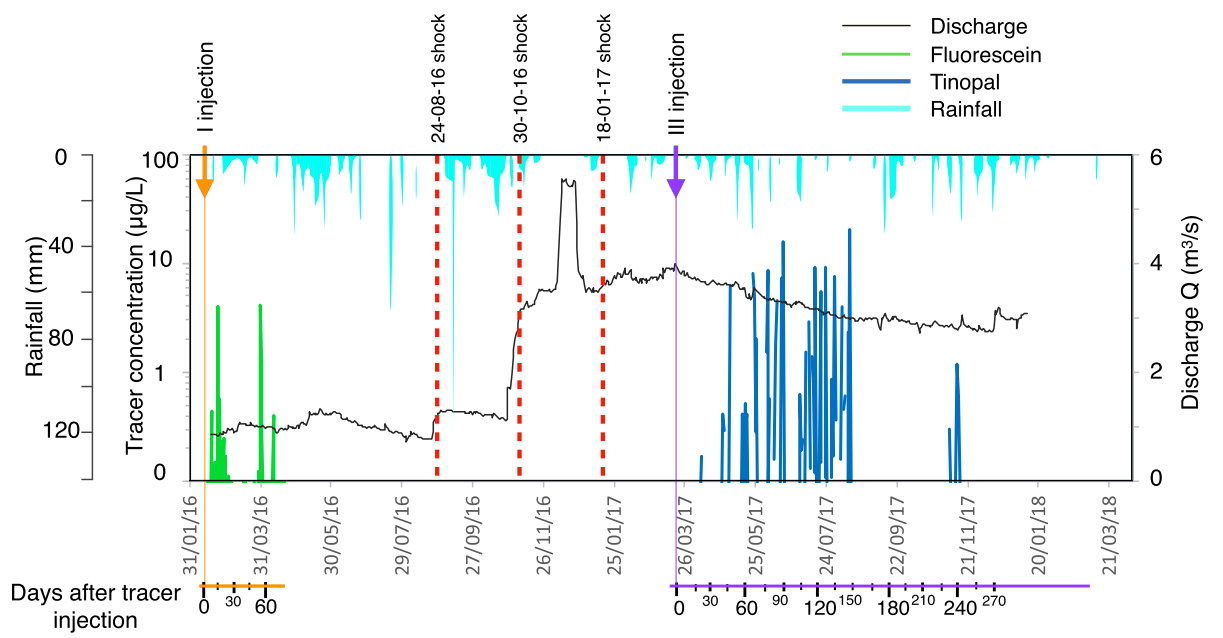


Fig. 11 Tracer breakthrough curves for the Nera linear springs (Pontenuovo)

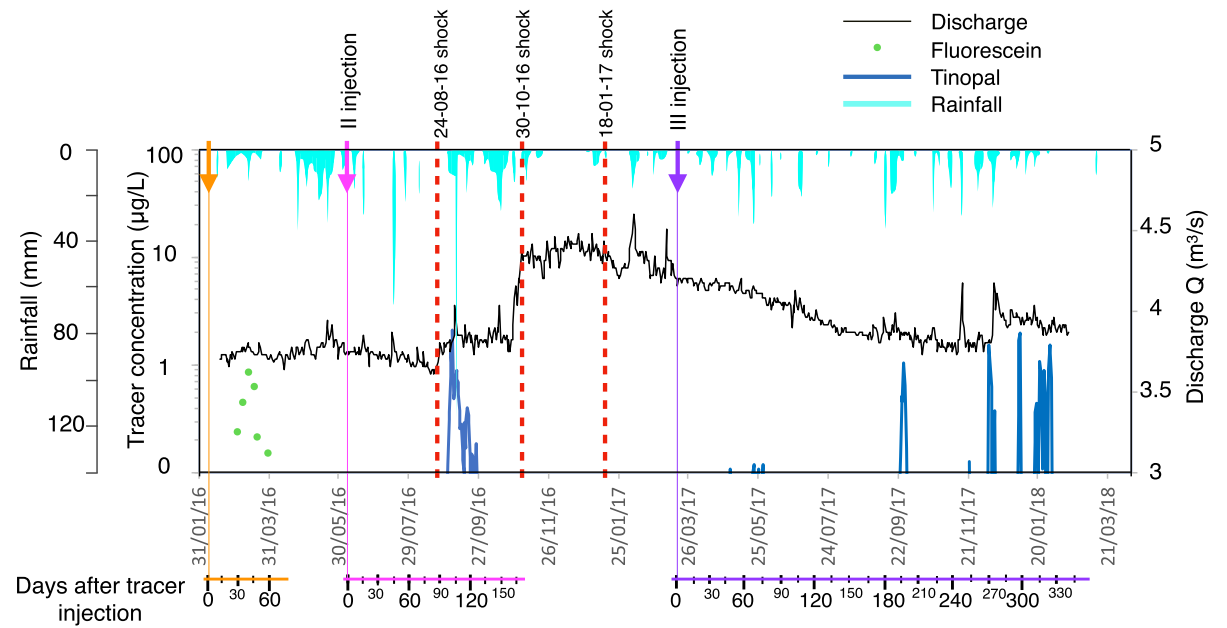

interpretation of data and to a lack of reliable data on single springs or aquifers. Qualitative observations can be made, and are presented further in this paragraph, while quantitative outcomes can involve only transit time, mean velocity and dispersivity of the investigated aquifers; mixing among different aquifers and hydro-structures can be identified but their amount (i.e. the exact volume involved in these processes) is still unknown. Only a rough estimation of hydraulic conductivity and piezometric level change after the earthquake can be made.

Regarding the springs on the Adriatic side, in the Pescara spring, only the tracer injected into the swallow hole during the second test in June 2016 (pre-earthquake) was detected, while in the Capodacqua spring, the tracer injected during the pre- and post-earthquake periods was recorded. The results of the first two tests show a rather fast water circuit for these springs, with tracer transit time very small (about 18 days, Table 2); the tracer BTCs show pulse features, typical of well-connected and interconnected conduits and fissures, and the arrival times are similar and very fast (left part of Figs. 6 and 7). The water circulation must take place in the shallow portion of the aquifer characterised by fissure and karst, the so-called epiphreatic portion of a karst aquifer.

The tracer tests therefore demonstrate that the two springs are in connection with the basal aquifer of the Castelluccio plain depression and that the springs' recharge takes place through a water circuit implemented along the fissured zones associated with the normal faults with Apennine direction, including the Mt. Vettore fault, which was reactivated by the 2016-2017 seismic events (Brozzetti et al. 2019). In particular, in the Pescara spring, emerging at higher elevations than the neighbouring Capodacqua spring, the discharge varies from approximately $0.02 \mathrm{~m}^{3} \mathrm{~s}^{-1}$ in the dry periods to $0.57 \mathrm{~m}^{3} \mathrm{~s}^{-1}$ (Table 1), thus highlighting a strong piezometric excursion of the recharging aquifer. The lack of tracer arrival at this spring after the earthquake might be likely attributable to the piezometric lowering induced by the August 2016 seismic sequence. After the sequence a change also in the Capodacqua spring behaviour occurred, with lower velocity (decreased by 90\%) and long residence time (almost eight times higher).

In the Foce spring, emerging directly from the Calcare Massiccio basal aquifer and approximately $3.5 \mathrm{~km}$ away from the Sibillini Mountains overthrust, the tracer injected during the first pre-earthquake test arrived after a long period of permanence in the basal aquifer of the Castelluccio plain (tracer transit time over 1 year). This means that the tracer had infiltrated and spread to a certain depth in the aquifer and that its mobilisation was entirely due to a pulse caused by seismic events between August and November 2016. In fact, these events increased the permeability of the basal aquifer, which has fostered the groundwater flow towards the Foce spring. The tracer BTC with pulse characteristics (left part of the Fig. 8) shows that the water circulation, similar to that in the previous springs, occurs in the upper part of the aquifer, the epiphreatic zone, by fissure and karst, as also reported by Jeannin (2001).

The BTC shape of the second and third tests is representative of baseflow transfer (i.e., enlarged shape and prolonged duration of tracer arrival, right part of the Fig. 8). The tracer concentration, in this case, was lower than that in the previous springs by one order of magnitude approximately.

This result highlights that the Foce spring drains a vast extension of the Sibillini basal aquifer, structural sectors of the Castelluccio plain and the eastern side of Mt. VettoreMt. Bove. The high discharges of the spring, which in the period before the 2016/2017 seismic events reached values well above $1.3 \mathrm{~m}^{3} \mathrm{~s}^{-1}$ and rarely less than $0.4 \mathrm{~m}^{3} \mathrm{~s}^{-1}$, justify the vast extension of the aquifer recharging the Foce spring. This set of factors indicates a diffusion and deep circulation typical of a fissured aquifer below the epikarst zone, featuring mainly a drainage network with hydro-dispersive circulation; 
Table 2 Interpretation of tracer tests before and after the earthquake. Parameter estimation was made using QTracer2 software (USEPA 2002) and MS Excel. lin. linear

\begin{tabular}{|c|c|c|c|c|c|c|c|}
\hline Monitoring period & Sample site & $\begin{array}{l}\text { Distance from } \\
\text { injection }(\mathrm{km})\end{array}$ & $\begin{array}{l}\text { Time of first arrival } \\
\text { of tracer (days) }\end{array}$ & $\begin{array}{l}\text { Mean tracer transit } \\
\text { time (days) }\end{array}$ & $\begin{array}{l}\text { Mean tracer velocity } \\
(\mathrm{m} / \text { day) }\end{array}$ & $\begin{array}{l}\text { Dispersivity } \\
\text { (m) }\end{array}$ & $\%$ tracer \\
\hline \multirow[t]{6}{*}{ Pre-earthquake } & Nera lin. springs & 18.8 & 26 & $88.2 \pm 6.9$ & $213.1 \pm 16.3$ & $8.10 \pm 6.31$ & $34 \%$ \\
\hline & Sordo lin. springs & 8.8 & 80 & $83.4 \pm 4.7$ & $105.5 \pm 4.7$ & $0.13 \pm 1.12$ & $40 \%$ \\
\hline & Capodacqua & 6.3 & 13 & $17.8 \pm 5.2$ & $353.8 \pm 82.9$ & $12.80 \pm 16.11$ & $8 \%$ \\
\hline & Pescara & 7.3 & 14 & $17.8 \pm 5.1$ & $410 \pm 96$ & $14.81 \pm 12.13$ & $8 \%$ \\
\hline & Foce & 12.6 & 255 & $401.3 \pm 21.4$ & $31.4 \pm 1.8$ & $18.19 \pm 15.32$ & $7 \%$ \\
\hline & S. Chiodo & 12.6 & 19 & $25.8 \pm 2.8$ & $1068.8 \pm 169.4$ & $110.31 \pm 46.23$ & $2 \%$ \\
\hline \multirow[t]{6}{*}{ Post-earthquake } & Nera lin. springs & 18.8 & 127 & $266.4 \pm 36.2$ & $137.8 \pm 19.8$ & $87.29 \pm 35.28$ & $11 \%$ \\
\hline & Sordo lin. springs & 8.8 & - & - & - & - & $0 \%$ \\
\hline & Capodacqua & 6.3 & 155 & $156.3 \pm 1.2$ & $40.3 \pm 0.3$ & $0.0002 \pm 0.29$ & $59 \%$ \\
\hline & Pescara & 7.3 & - & - & - & - & $0 \%$ \\
\hline & Foce & 12.6 & 95 & $301.6 \pm 46.5$ & $41.78 \pm 6.83$ & $2.03 \pm 5.02$ & $18 \%$ \\
\hline & S. Chiodo & 12.6 & 54 & $106.1 \pm 44.6$ & $146.3 \pm 156.5$ & $1694 \pm 358$ & $12 \%$ \\
\hline
\end{tabular}

this is correlated with the post-earthquake decrease in the piezometric level in the eastern sector of the basal aquifer. This phenomenon is connected to the increase in the volume of water drained towards the western and northern sectors of the same aquifer, shown by the rise of the discharge data (Figs. 9, 10, and 11), which is a direct effect of the groundwater circuit changes induced by the 2016 earthquake. Overall, a flow rate deficit of about $2 \mathrm{~m}^{3} \mathrm{~s}^{-1}$ was recorded in the monitored points of the Adriatic side right after the seismic shocks, while towards northern and western boundaries an increase of at least $7 \mathrm{~m}^{3} \mathrm{~s}^{-1}$ was observed. The flow rates of the Foce spring showed a slow and constant decrease to the current values of approximately $0.2 \mathrm{~m}^{3} \mathrm{~s}^{-1}$, about $80 \%$ of the preearthquake discharge (Fig. 8). Finally, the different tracer arrival times at the spring could also be attributable to the introduction into the water circuit of labelled waters trapped deep in the aquifer. Here, the progressive lowering of the piezometric level over time can gradually favour their introduction in the water circuit recharging the spring, as also supported by the chemical changes in the spring water composition (Fig. 12), where magnesium and, above all, sulphates substantially increased after the earthquake by two or three times. Major content of magnesium and sulphates can indicate deeper circuits involved in groundwater flow after the seismic sequence.

Regarding the springs on the western side, at the San Martino spring, fed directly from the basal aquifer, the tracer arrived after 8 days (left part of the Fig. 9), demonstrating that the karst phenomenon is rather well developed also in the western sector of the Sibillini Mountains.

In contrast, the appearance of the tracer at the linear springs of the Sordo River in approximately 80 days highlights a complex groundwater circuit (Fig. 9; Table 2). These springs emerge from the continental deposits of the tectonic depression of the Santa Scolastica plain, where the thick porous aquifer shows hydraulic conductivity clearly inferior to that of the surrounding limestone. This aquifer, in tectonic contact via the normal fault Nottoria-Norcia-Preci (Galli et al. 2005; Pizzi and Galadini 2009), is therefore in hydraulic continuity with the basal aquifer of the western sector of the Sibillini Mountains. The tracer injected into the sinkhole arrived quickly at the continental aquifer of the plain and was conveyed and detected at the "Marcite of Norcia" area with less velocity. Based only on the tracer outcomes, an average flow rate of $22 \mathrm{~m} /$ day can be assumed in the plain deposits compared with a faster circulation in the carbonatic rocks (around $800 \mathrm{~m} /$ day in the $\mathrm{S}$. Martino spring). The trend of

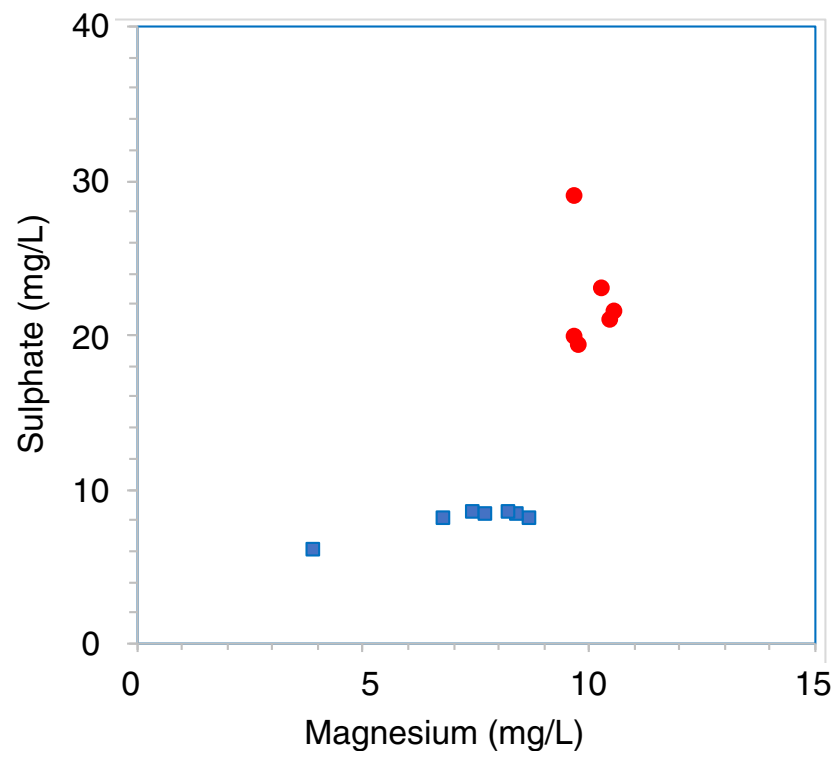

Fig. 12 Cross plot of sulphate vs. magnesium in the Foce spring. Blue squares are values measured from 28 January 2016 to 12 April 2016, red circles from 31 August 2016 to 12 May 2017 
the hydro-dispersive curve (Fig. 9) is therefore justified by this type of circulation, which was also affected by the strong increase in the hydraulic load in the plain aquifer caused by the 2016 seismic event.

The sudden reappearance of the Torbidone spring in the plain, following the earthquake of October 2016, was probably almost entirely due to groundwater transfer from the lowest part of the aquifer because of rise in the piezometric level and the subsequent increase in water volumes towards the western hydrogeologic boundary, where the flow occurred in deep circuits not yet marked by the tracer test, as shown in the right part of the Fig. 9 where the tracer was not revealed during the third test. Further investigations are needed to shed light on this theory.

Finally, with regard to the northern side, at the San Chiodo spring, the tracer arrived with pulse-type modes similar to those in the first pre-earthquake test and in the third postearthquake test, indicating circulation in a karstic and fissured system typical of the epiphreatic portion of the aquifer (Fig. 10). There were noticeable differences, not in the shape of the BTCs but in the duration of the pulses and in the spring discharge. In the post-earthquake test, the arrival and disappearance of the tracer took much longer than in the previous phase; in the pre-earthquake phase, the tracer curve developed when the flow rate was approximately $0.8 \mathrm{~m}^{3} \mathrm{~s}^{-1}$, while in the post-seismic phase, the flow rate was higher (approximately $3.3 \mathrm{~m}^{3} \mathrm{~s}^{-1}$ ), in conjunction with the increase in the hydraulic load of the aquifer caused by the seismic event. This increase likely favoured the flow of the tracer trapped in that portion, thus justifying the relatively longer arrival and disappearance times of the tracer in the post-earthquake phase.

The tracer tests also show that the groundwater circulation is consistent with the geo-structural layout of the Sibillini: in fact, the fold axes dip S-NW towards the Nera River, thus favouring the increase in spring flow rates due to the change in the basal aquifer piezometric level.

The arrival of the tracer at the linear springs of the Nera River (Pontenuovo) can indicate that the overthrust of the Valnerina-Mt. Fema (Figs. 1 and 3) is likely released by faults that allow hydraulic contact between the Castelluccio plain and the Nera River; otherwise, the geo-structural features of the area would be different from those reported in the literature (Pierantoni et al. 2013 and references therein).

The first test (pre-earthquake) was performed during the period of the winter aquifer recharge, characterised by high volumes of water that infiltrated the swallow hole. The arrival of the tracer, 26 days after injection, showed a very fast circulation that developed in the shallow part of the aquifer (epikarst area).

In the second test, which took place at the end of the aquifer recharge period, the longest arrival time (approximately 130 days) is not easy to interpret. Tracer infiltration to a greater depth in the aquifer with slower transport to the spring is feasible. However, the seismic event of August 2016 gave a considerable boost to the mobilisation of water in the aquifer, increasing the hydraulic conductivity and therefore quickening the tracer arrival, which occurred only 6 days after the August seismic shock. The BTCs in the two tests are similar, showing that the water circulation always occurred through fissures and karst (Fig. 11).

In the third (post-earthquake) test, the tracer arrival and disappearance curves are typically impulsive, containing repeated peaks with an interval of approximately 6 months during the recession limb of the hydrograph, with values similar to those of the pre-earthquake period. Additionally, for the linear springs of the Nera River (Pontenuovo), similar to the San Chiodo spring, one can hypothesise the same hydrogeological phenomenology that justifies the long arrival and disappearance times of the tracer in the third test.

Figure 13 summarises the hypothesised flow path directions for the investigated springs resulting from the tracer tests; from a geo-structural point of view, three sectors can be identified (Adriatic sector, central sector and western sector), while hydrogeochemical behaviour of the springs emerging near the Mt Sibillini overthrust and tracer test results lead to a scheme like that in Fig. 13. In the first test (Fig. 13a), the majority of the tracer spread out along the central sector; after the earthquake, in a first stage all the sectors were involved with different percentages (Fig. 13b), in a second stage the central sector is again the main direction of tracer spread (Fig. 13c). Mean transit times per km were very high in the S. Chiodo spring (northern boundary, 0.93 days $/ \mathrm{km}$ ) and Capodacqua and Pescara springs (about 3 days $/ \mathrm{km}$, southern part of the Adriatic side) before the seismic sequence, thus indicating groundwater circulation in a well-developed karst system localized in the upper part of the aquifers. After the earthquake, the great increase of mean transit time in the Capodacqua spring (about 25 days $/ \mathrm{km}$ ) is connected to a very low value of the dispersivity (Table 2), as a result of a change in groundwater circulation, now affecting also the lower part of the aquifers with flow occurring in well-defined karst conduits.

The results reported in Table 2 indicate that after the earthquake the amount of tracer reaching the Adriatic side (and therefore the volume of groundwater involved) has been strongly increased (by three times), while in the northern area fewer changes have been registered. The table also reports the safety time (i.e. the time of first arrival of tracer) for each monitored point, highlighting different values before and after the earthquake; some springs are characterized by very low safety time, thus indicating a major potential exposure to pollutants that can infiltrate the sinkhole and reach the spring. Such points should be carefully protected especially in the recharge areas, as only 2 or 3 weeks are needed to move a contaminant from the Castelluccio plain through faster karstic conduits until the spring. The flow velocity has been in fact 


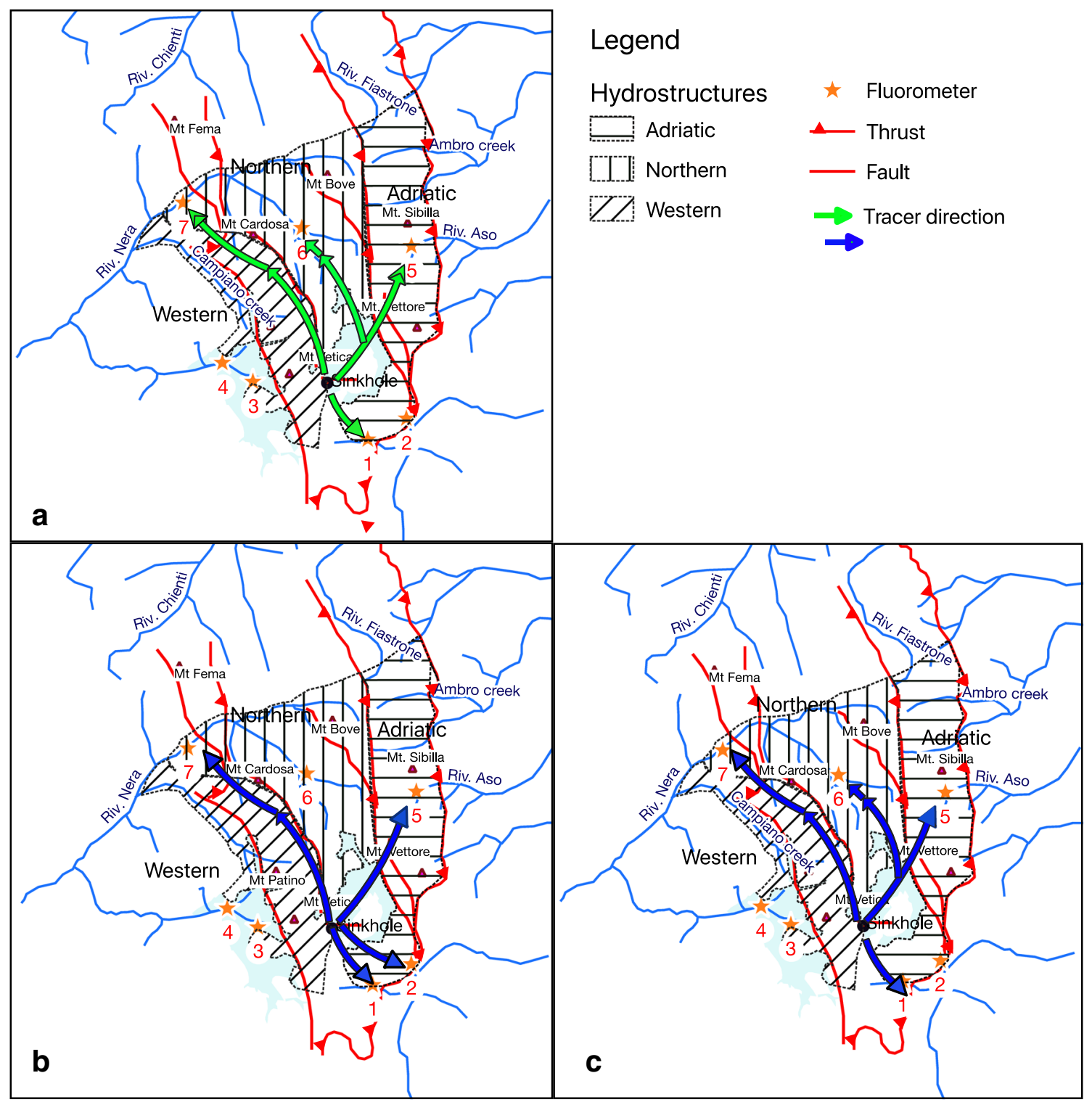

Fig. 13 Main schematic flow paths, with hydrogeological and structural sectors, derived from the a first, $\mathbf{b}$ second and $\mathbf{c}$ third tests

reduced in all the monitored points except for the Foce spring, where the velocity slightly increased, and the shape of the BTCs and the tracer arrival time in the pre- and postearthquake periods have been changed. Even the tracer tests, therefore, as well as the observation of the flow rate change in the different sectors, confirm a dramatic modification of the groundwater flow after the seismic shocks. Similar responses among the aquifers, in terms of hydraulic conductivity increase in some areas and piezometric lowering in other ones, although common to other situations in Italy and around the world involving seismic events (Manga et al. 2003; Elkhoury et al. 2006; Liu and Manga 2009; Falcone et al. 2010; Amoruso et al. 2011; Manga and Wang 2015; Wang et al. 2016; De Luca et al. 2016, 2018), are peculiar in this area. In fact, the first seismic shock produced similar effects to those noticed in other earthquakes (see, for example, Amoruso et al.
2011), while the second and third ones (2016, October), characterized by higher magnitude, caused the actual variation in the groundwater circuits.

In general, the total flow rate increase recorded in the western and northern sectors after the seismic crisis is much higher than the lowering in the discharge measured in the Adriatic springs. The difference (more than $5 \mathrm{~m}^{3} \mathrm{~s}^{-1}$ ) is a consequence of the hydraulic conductivity boost towards the western and northern boundaries, which induced the discharges measured in these sides. Earthquakes, in fact, likely cleaned joints, fissures and fractures in the carbonate aquifers, thus inducing the increase of the hydraulic conductivity and forced this growth in the flow rates in the initial stage (during the transient). After that, the release of the Mt. Vettore fault (Brozzetti et al. 2019) caused the lowering of the piezometric level in the Adriatic side; the groundwater circulation strongly modified its pattern, 
activating several conduits of flow (fissures and fractures) and moving close (in some areas) to an almost hydrodispersive pattern. Before the seismic shock, groundwater movement occurred in already structured and long-time arranged preferential conduits in which karst played a basic role; after the earthquake, flow paths were re-arranged and affected a large number of fractures and fissures. This fact would be consistent both to the flow rate increments in the western and northern sides and to the general drop of flow velocity recorded in almost all points during the tracer tests (Table 2); the higher the discharge, the higher the volume of aquifer affected by flow and the lower the velocity. The flow velocity has been, in fact, reduced at all the monitored points except for the Foce spring, where the velocity slightly increased, and the shape of the BTCs and the tracer arrival time in the pre- and postearthquake periods have changed. Even the tracer tests, therefore, as well as the observation of the flow rate change in the different sectors, confirm a dramatic modification of the groundwater flow after the seismic shocks.

A rough estimation of this increment - based on the hydraulic gradient measured along the linear springs axis, the flow rate increments and the literature data (Boni and Petitta 2007)—leads to hydraulic conductivity around one order of magnitude higher in the western and northern sectors (from $3 \times 10^{-6}$ to $2 \times 10^{-5} \mathrm{~m} / \mathrm{s}$ ) after the earthquake and a piezometric lowering in the Adriatic sector of about $30 \mathrm{~m}$.

As a final remark, the quantitative outcomes of this study have been obtained in a preliminary stage and need to be confirmed by further and more specific investigations, involving single springs and involving other techniques and measurements. The amount of tracer recovered after the tests, and the flow path re-directions, reveals that only some areas are connected to the Castelluccio plain significantly; the other areas show a link but only a few percent of the total groundwater discharged into linear and point springs may be directly attributable to the sinkhole area. In particular, in the northern sector the total mass recovery reduced from $2.5 \mathrm{~kg}$ before to $0.5 \mathrm{~kg}$ after the earthquake, indicating a lesser importance of the karst network's (present in the Castelluccio plain) role on the total flow rate. In the Adriatic side, after the seismic shock, the majority of the tracer is directed towards the Capodaqua spring; total mass recovered remained almost the same.

\section{Conclusions}

The tracer tests conducted in the carbonate massif of the Sibillini Mountains show the importance of this experimental technique in the hydrogeological study of areas characterized by karst phenomena and complex geo- structural setting. The results highlight the presence of a unique and powerful basal aquifer in the Calcare Massiccio hydrogeological complex, with hydrostructural sectors mutually in hydraulic tectonic contact. These contacts are due to the presence of normal Quaternary faults with displacements greater than $500 \mathrm{~m}$, also responsible for the geo-structural step framework proceeding from the overthrust of the Sibillini Mountains (eastern side) in the direction of the Santa Scolastica plain (western side). This peculiar geostructural arrangement, typical of large part of the Apennine chain, allows hydraulic contact between the three structural sectors of the basal aquifer of the Calcare Massiccio complex and between the latter and the above aquifers of the Maiolica and Scaglia complexes. These features are to be considered relevant for all the carbonate Apennines.

In fact, the seismic events of 2016/2017 in central Italy greatly increased the hydraulic conductivity of the basal aquifer (at least by one order of magnitude), changing its groundwater circulation and influencing the flow rate of the springs it supplies. This increase has also led to a change in the prevalent direction of the groundwater flow confirmed as well by the tracer tests, from the eastern geo-structural sector of the Sibillini to the western sector in the direction of the Santa Scolastica plain (western side) and the Nera River to the N-W. This change also explains the strong flow rate increase (over $7 \mathrm{~m}^{3} \mathrm{~s}^{-1}$ ) of the springs and linear springs fed by the basal aquifer outcropping in the western and northern hydrogeological boundaries of the Sibillini massif and, on the other hand, the dramatic reduction in the flow rate of the springs on the eastern Adriatic side (about $2 \mathrm{~m}^{3} \mathrm{~s}^{-1}$ ) and the following piezometric lowering by almost $30 \mathrm{~m}$. This also explains the disappearance of some springs emerging at high elevation in the eastern slope of the Sibillini. It is expectable that similar phenomena occur in other areas of the Apennine chain affected by seismic activity, with serious repercussions in the supply of the aqueduct network.

The analysis of the BTCs in the pre- and postearthquake periods allowed one to define the hydraulic characteristics and groundwater circulation flow paths of the Sibillini basal aquifer and these features can be extended to other similar aquifers affected by seismicinduced variations. The analysis of the tracer results has also improved the information about karst phenomena (not well known in the Sibillini massif) affecting the basal carbonate aquifer and stressed the effects of the earthquake on water circulation in large areas and for long periods of time. In such environments, all the springs should be protected in their recharge area, since the time of first arrival of tracer is often very short, thus indicating a great vulnerability. 
The tracer recovery in the springs during the preearthquake period shows that the characteristics of the basal aquifer can be associated with those of a karst aquifer in which the water circulation develops in the epiphreatic area characterised by fissures and karst. The groundwater velocity, as seen from the tracer BTC, is very high.

Tracer tests performed after the 2016/2017 seismic events showed different arrival and disappearance characteristics for the springs of the eastern and northwestern sectors of the Sibillini. In the north-western sectors, there was a considerable increase in flow rates, while in the eastern area, there was an evident decline. This result is related to the variations in the piezometric level of the basal aquifer following the earthquake; such variations are different in the three sectors, reflecting a transfer of large volumes of groundwater from the eastern structural sector to the north-western sectors. More specifically, in the eastern sector, the arrival of the tracer at the Foce spring, associated with the constant lowering of the piezometric line, highlights that water circulation takes place in a fissured aquifer with a dispersive network regime. In the springs of the north-western sector, by contrast, the arrival of the tracer, associated with high and pulse-like flow rates, shows that the water circulation is faster and takes place in the epiphreatic area characterised by karstification and fissures.

In brief and more in general, the tracer tests show that the Sibillini complex is a single wide aquifer characterised by three different hydro-structural sectors hydraulically connected. The results of these tests suggest that the basal aquifer of the Sibillini Mountains is a karst and fissured aquifer in which two kinds of circuits are present: the circulation in the epiphreatic shallow zone which is very fast, while in the deepest part of the aquifer, mainly characterised by fissures and presumable micro-karst, circulation is slower and exhibits hydro-dispersive behaviour. Considering all the qualitative and quantitative observations given above about flowpath direction and potential hydraulic connections among different aquifers and hydro-structures, it is important to note that only some connections are actual and relevant for the water budget of an aquifer or a spring. In some cases, in fact, especially after the earthquake, the percentage of groundwater marked by the tracer is still too low to be relevant. In other points, in contrast, the maximum velocity can rise (in particular during the recharge period) leading to a vulnerability increase in the hydrogeological system.

Lastly, the hydrogeological analysis of a carbonate area needs extensive knowledge of its geo-structural setting (useful also to correctly plan the experimental tests); when it is lacking, tracer tests provide essential data and results for defining the groundwater circulation in an area characterized by frequent seismic sequences that alter the natural flowpaths.

Acknowledgements The authors appreciate the contributions of the anonymous reviewers. The authors would like to thank CIIP SpA for the supply of results concerning the spring discharges.

Funding information The authors also thank CIIP SpA for the financial support in the research.

Open Access This article is licensed under a Creative Commons Attribution 4.0 International License, which permits use, sharing, adaptation, distribution and reproduction in any medium or format, as long as you give appropriate credit to the original author(s) and the source, provide a link to the Creative Commons licence, and indicate if changes were made. The images or other third party material in this article are included in the article's Creative Commons licence, unless indicated otherwise in a credit line to the material. If material is not included in the article's Creative Commons licence and your intended use is not permitted by statutory regulation or exceeds the permitted use, you will need to obtain permission directly from the copyright holder. To view a copy of this licence, visit http://creativecommons.org/licenses/by/4.0/.

\section{References}

Amoruso A, Crescentini L, Petitta M, Rusi S, Tallini M (2011) Impact of the 6 April 2009 L'Aquila earthquake on groundwater flow in the Gran Sasso carbonate aquifer, central Italy. Hydrol Process 25: 1754-1764. https://doi.org/10.1002/hyp.7933

Aquilanti L, Clementi F, Landolfo S, Nanni T, Palpacelli S, Tazioli A (2013) A DNA tracer used in column tests for hydrogeology applications. Environ Earth Sci 70:3143-3154. https://doi.org/10.1007/ s12665-013-2379-y

Aquilanti L, Clementi F, Nanni T, Palpacelli S, Tazioli A, Vivalda PM (2016) DNA and fluorescein tracer tests to study the recharge, groundwater flowpath and hydraulic contact of aquifers in the Umbria-Marche limestone ridge (central Apennine, Italy). Environ Earth Sci 75:626. https://doi.org/10.1007/s12665-016-5436-5

Aringoli D, Cavitolo P, Farabollini P, Galindo-Zaldivar J, Gentili B, Giano SI, Lòpez-Garrido AC, Materazzi M, Nibbi L, Pedrera A, Pambianchi G, Ruano P, Ruiz-Constàn A, Sanz de Galdeano C, Savelli D, Tondi E, Troiani F (2014) Morphotectonic characterization of the Quaternary intermontane basins of the Umbria-Marche Apennines (Italy). Rend Fis Acc Lincei 25:111-128. https://doi.org/ 10.1007/s12210-014-0330-0

Aringoli D, Bufalini M, Farabollini P, Fazzini M, Fuffa E, Giacopetti M, Ianni C, Materazzi M, Pambianchi G, Pierantoni PP, Scalella G (2018) La sequenza sismica 2016-2018 nel Centro-Italia: effetti geomorfologici e variazioni idrologiche ed idrogeologiche nell'area epicentrale appenninica [The 2016-2018 seismic sequence in central Italy: geomorphological effects and hydrological and hydrogeological variations in the Apennine epicentral area]. Geologi March 1(2018):10-17

Bally AW, Burby L, Cooper CJ, Ghelardoni P (1986) Balanced sections and seismic reflection profiles across the central Apennines. Mem Soc Geol It 35:257-310

Barchi M, Alvarez W, Shimabukuro DH (2012) The Umbria-Marche Apennines as a double orogen: observations and hypotheses. Ital $\mathbf{J}$ Geosci 131:258-271. https://doi.org/10.3301/IJG.2012.17

Biella G, Lavecchia G, Lazey A, Pialli G, Scarascia S (1981) Primi risultati di un'indagine geofisica e interpretazione geologica del 
piano di S. Scolastica e del Piano Grande (Norcia, Pg.) [First results of the geophysical survey and geological interpretation of the S. Scolastica plain and Piano Grande]. Atti I Convegno GNGTS, pp 293-308

Boccaletti M, Calamita F, Viandante MG (2005) La Neocatena litosferica appenninica nata a partire dal Pliocene inferiore come espressione della convergenza Africa-Europa [The lithospheric Apennine neochain ridge born from the late Pliocene as an expression of the Africa-Europe convergence]. Boll Soc Geol It 124:87-105

Boni C (2010) Studio idrogeologico per l'identificazione, la caratterizzazione e la gestione degli acquiferi del parco nazionale dei monti Sibillini [Hydrogeological study for identification, characterisation and management of groundwater resources in the Sibillini Mountains National Park (central Italy)]. Ital J Eng Geol Environ 2:21-39. https://doi.org/10.4408/IJEGE.2010-02.O-02

Boni C, Petitta M (2007) Studio idrogeologico per l'identificazione e la caratterizzazione degli acquiferi che alimentano le sorgenti dei corsi d'acqua perenni dei Monti Sibillini, esteso all'intera area del Parco Nazionale [Hydrogeological study for the identification and characterization of aquifers recharging the springs of the perennial streams of the Sibillini Mountains, extended to the whole area of the National Park]. Technical note, Dip. Scienze della Terra, Università La Sapienza di Roma, Autorità di bacino del F. Tevere, Parco Nazionale dei Monti Sibillini

Boni CF, Bono P, Capelli G (1986) Schema idrogeologico dell'Italia Centrale [Hydrogeological scheme of central Italy]. Mem Soc Geol It 35:991-1012

Brozzetti F, Boncio P, Cirillo D, Ferrarini F, de Nardis R, Testa A, Liberi F, Lavecchia G (2019) High-resolution field mapping and analysis of the August-October 2016 coseismic surface faulting (central Italy earthquakes): slip distribution, parameterization, and comparison with global earthquakes. Tectonics 38:417-439

Calamita F, Coltorti M, Deiana G, Dramis F, Pambianchi G (1982) Neotectonic evolution and geomorphology of the Cascia and Norcia depressions (Umbria-Marche Apennine). Geogr Fis Din Quat 5:263-276

Calamita F, Coltorti M, Farabollini P, Pizzi A (1994) Le faglie normali quaternarie nella dorsale appenninica umbro-marchigiana: proposta di un modello di tettonica di inversione [Normal Quaternary faults in the Umbria-Marche ridge: proposal of a tectonic model of inversion]. Studi Geol Camerti Vol Spec 1:211-225

Calamita F, Satolli S, Turtù A (2012) Analysis of thrust shear zones in curve-shaped belts: deformation mode and timing of the OlevanoAntrodoco-Sibillini thrust (central/northern Apennines of Italy). J Struct Geol 44:179-187. https://doi.org/10.1016/j.jsg.2012.07.007

Caprari M, Nanni T (1999) Idrogeologia della dorsale carbonatica del M. Catria-M. Nerone (Appennino umbro-marchigiano settentrionale) [Hydrogeological setting of the carbonate ridge of the Mt Catria-Mt Nerone, Umbia-Marche Apennines]. Boll Soc Geol It 118:563-584

Carminati E, Doglioni C (2012) Alps vs. Apennines: the paradigm of a tectonically asymmetric earth. Earth Sci Rev 112:67-96. https://doi. org/10.1016/j.earscirev.2012.02.004

Centamore E, Micarelli A (1991) Stratigrafia [Stratigraphy]. In: L'Ambiente fisico delle Marche. SELCA, Florence, pp 5-58

Centamore E, Rossi D, Tavarnelli E (2009) Geometry and kinematics of Triassic-to-recent structures in the northern-central Apennines: a review and an original working hypothesis. Ital J Geosci 128:419 432. https://doi.org/10.3301/IJG.2009.128.2.419

Chiaraluce L, Di Stefano R, Tinti E, Scognamiglio L, Michele M, Casarotti E, Cattaneo M, De Gori P, Chiarabba C, Monachesi G (2017) The 2016 central Italy seismic sequence: a first look at the mainshocks, aftershocks, and source models. Seismol Res Lett 88: 757-771

Coltorti M, Farabollini P (1995) Quaternary evolution of the Castelluccio di Norcia basin (Umbro-Marchean Apennines, Italy). Il Quatern Ital J Quatern Sci 8:149-166
De Luca GD, Carlo GD, Tallini M (2016) Hydraulic pressure variations of groundwater in the Gran Sasso underground laboratory during Amatrice earthquake of August 24th, 2016. Ann Geophys 59:1-6. https://doi.org/10.4401/ag-7200

De Luca G, Di Carlo G, Tallini M (2018) A record of changes in the gran Sasso groundwater before, during and after the 2016 Amatrice earthquake, central Italy. Sci Rep 8:15982. https://doi.org/10.1038/ s41598-018-34444-1

Deiana G, Pialli G (1994) The structural provinces of the UmbroMarchean Apennines. Mem Soc Geol It 48:473-484

Di Domenica A, Turtù A, Satolli S, Calamita F (2012) Relationships between thrusts and normal faults in curved belts: new insight in the inversion tectonics of the central-northern Apennines (Italy). J Struct Geol 42:104-117. https://doi.org/10.1016/j.jsg.2012.06.008

Elkhoury JE, Brodsky EE, Agnew DC (2006) Seismic waves increase permeability. Nature 441:1135-1138. https://doi.org/10.1038/ nature 04798

Falcone G, Console R, Murru M (2010) Short-term and long-term earthquake occurrence models for Italy: ETES, ERS and LTST. Ann Geophys 53:41-50

Galli P, Galadini F, Calzoni F (2005) Surface faulting in Norcia (central Italy): a "paleoseismological perspective." Tectonophysics 403: 117-130. https://doi.org/10.1016/j.tecto.2005.04.003

Giovagnotti C (1975) Lineamenti paleogeografici e geomorfologici dei Monti Sibillini [Paleogeographical and geomorphological features of the Sibillini Mountains]. Atti Soc It Biogeogr VI:29-80

Goldscheider N, Meiman J, Pronk M, Smart C (2008) Tracer tests in karst hydrogeology and speleology. Int J Speleol 37:27-40. https://doi. org/10.5038/1827-806X.37.1.3

Jeannin P-Y (2001) Modeling flow in phreatic and epiphreatic karst conduits in the Hölloch Cave (Muotatal, Switzerland). Water Resour Res 37:191-200. https://doi.org/10.1029/2000WR900257

Lauber U, Goldscheider N (2014) Use of artificial and natural tracers to assess groundwater transit-time distribution and flow systems in a high-alpine karst system (Wetterstein Mountains, Germany). Hydrogeol J 22:1807-1824. https://doi.org/10.1007/s10040-0141173-6

Lavecchia G (1985) Il sovrascorrimento dei Monti Sibillini: analisi cinematica e strutturale [The Mts. Sibillini overthrust: cinematic and structural analysis]. Boll Soc Geol It 104:161-194

Lippi Boncambi C (1950) Considerazioni pedologiche sui Monti Sibillini ed in particolare sui terreni torbosi dell'altopiano del Castelluccio di Norcia [Soil observations on the Sibillini Mountains, in particular on the peaty soils of the Castelluccio di Norcia plain]. Boll Soc Geol It 69:26-37

Liu W, Manga M (2009) Changes in permeability caused by dynamic stresses in fractured sandstone. Geophys Res Lett 36:L20307. https://doi.org/10.1029/2009GL039852

Luzi L, Pacor F, Puglia R, Lanzano G, Felicetta C, D’Amico M, Michelini A, Faenza L, Lauciani V, Iervolino I, Baltzopoulos G, Chioccarelli E (2017) The central Italy seismic sequence between August and December 2016: analysis of strong-motion observations. Seismol Res Lett 88:1219-1231. https://doi.org/10.1785/ 0220170037

Manga M, Wang C-Y (2015) Earthquake hydrology. In: Schubert G (ed) Treatise on geophysics, 2nd edn. Elsevier, Oxford, pp 305-328

Manga M, Brodsky EE, Boone M (2003) Response of streamflow to multiple earthquakes: streamflow and earthquakes. Geophys Res Lett 30:1214. https://doi.org/10.1029/2002GL016618

Mastrorillo L, Baldoni T (2009) Analisi idrogeologica quantitativa del dominio carbonatico umbro [Quantitative hydrogeological analysis of the carbonate domain of the Umbria region]. Ital J Eng Geol Environ. https://doi.org/10.4408/IJEGE.2009-01.O-08

Mastrorillo L, Petitta M (2014) Hydrogeological conceptual model of the upper Chienti River basin aquifers (Umbria-Marche Apennines). Ital J Geosci 133:396-408. https://doi.org/10.3301/IJG.2014.12 
Mazzoli S, Pierantoni PP, Borraccini F, Paltrinieri W, Deiana G (2005) Geometry, segmentation pattern and displacement variations along a major Apennine thrust zone, central Italy. J Struct Geol 27:19401953. https://doi.org/10.1016/j.jsg.2005.06.002

Mirabella F, Barchi MR, Lupattelli A (2008) Seismic reflection data in the Umbria Marche region: limits and capabilities to unravel the subsurface structure in a seismically active area. Ann Geophys 51: 383-396

Mudarra M, Andreo B, Marín AI, Vadillo I, Barberà JA (2014) Combined use of natural and artificial tracers to determine the hydrogeological functioning of a karst aquifer: the Villanueva del Rosario system (Andalusia, southern Spain). Hydrogeol J 22:10271039. https://doi.org/10.1007/s10040-014-1117-1

Nanni T, Rusi S (2001) Correlation between the melting of the snows and the chemical-physical characteristics of springs, like parameter for the evaluation of karst aquifer vulnerability in central Apennine. In: Proc. of the 7th conference on limestone hydrology and fissured media, Besançon, France, September 2001, pp 261-264

Nanni T, Vivalda PM (2005) The aquifers of the Umbria-Marche Adriatic region: relationships between structural setting and groundwaters chemistry. Boll Soc Geol It 124:523-542

Nanni T, Vivalda PM, Marcellini M, Palpacelli S (2006) Spring monitoring and analysis of groundwater circulation in the Sibillini Mountains aquifers [Adriatic side of central Apennine, Italy]. Presses Universitarires Franche Comté, Neuchatel, Switzerland, pp 197-200

Nanni T, Tazioli A, Vivalda P (2013) Problems in the application of environmental isotopes to the hydrogeology of high mountain aquifers. AQUA Mundi 2038-3584(4):55-66. https://doi.org/10.4409/ Am-055-13-0052

Pace P, Domenica AD, Calamita F (2014) Summit low-angle faults in the central Apennines of Italy: younger-on-older thrusts or rotated normal faults? Constraints for defining the tectonic style of thrust belts. Tectonics 33:756-785. https://doi.org/10.1002/2013TC003385

Petitta M, Mastrorillo L, Preziosi E, Banzato F, Barberio MD, Billi A, Cambi C, De Luca G, Di Carlo G, Di Curzio D, Di Salvo C, Nanni T, Palpacelli S, Rusi S, Saroli M, Tallini M, Tazioli A, Valigi D, Vivalda PM, Doglioni C (2018) Water-table and discharge changes associated with the 2016-2017 seismic sequence in central Italy: hydrogeological data and a conceptual model for fractured carbonate aquifers. Hydrogeol J 26:1009-1026. https://doi.org/10.1007/ s10040-017-1717-7

Pierantoni PP, Deiana G, Galdenzi S (2013) Stratigraphic and structural features of the Sibillini Mountains (Umbria-Marche Apennines, Italy). Ital J Geosci 132:497-520. https://doi.org/10.3301/IJG. 2013.08

Pizzi A, Galadini F (2009) Pre-existing cross-structures and active fault segmentation in the northern-central Apennines (Italy). Tectonophysics 476:304-319. https://doi.org/10.1016/j.tecto.2009. 03.018

Pizzi A, Scisciani V (2000) Methods for determining the PleistoceneHolocene component of displacement on active faults reactivating
pre-Quaternary structures: examples from the central Apennines (Italy). J Geodyn 29:445-457. https://doi.org/10.1016/S02643707(99)00053-8

Qi J, Xu M, Cen X, Wang L, Zhang Q (2018) Characterization of karst conduit network using long-distance tracer test in Lijiang, southwestern China. Water 10:949. https://doi.org/10.3390/w10070949

Ravbar N, Barberá JA, Petrič M, Kogovšek J, Andreo B (2012) The study of hydrodynamic behaviour of a complex karst system under lowflow conditions using natural and artificial tracers [The catchment of the Unica River, SW Slovenia]. Environ Earth Sci 65:2259-2272. https://doi.org/10.1007/s12665-012-1523-4

Scisciani V (2009) Styles of positive inversion tectonics in the central Apennines and in the Adriatic foreland: implications for the evolution of the Apennine chain (Italy). J Struct Geol 31:1276-1294. https://doi.org/10.1016/j.jsg.2009.02.004

Tarragoni C (2006) Determinazione della "quota isotopica" del bacino di alimentazione delle principali sorgenti dell'alta Valnerina [Evaluation of the isotopic recharge elevation of the main springs]. Geol Romana 39:55-62

Tazioli GS, Cocchioni M, Coltorti M, Dramis F, Mariani M (1990) Circolazione idrica e chimismo del-le acque sotterranee dell'area carsica di Frasassi nelle Marche [Water circulation and chemistry of the groundwater of the karst area of Frasassi in the Marche]. Mem dell'Istituto Ital Speleol 4:93-108

Tazioli A, Aquilanti L, Clementi F, Marcellini M, Nanni T, Palpacelli S, Vivalda PM (2016) Hydraulic contacts identification in the aquifers of limestone ridges: tracer tests in the Montelago pilot area (central Apennines). Acque Sott 5:7-15. https://doi.org/10.7343/as-2016209

Tazioli A, Aquilanti L, Clementi F, Marcellini M, Nanni T, Palpacelli S, Roncolini A, Vivalda PM (2019) Flow parameters in porous alluvial aquifers evaluated by multiple tracers. Rend Online Soc Geol Ital 47:126-132. https://doi.org/10.3301/ROL.2019.23

US EPA (2002) The Qtracer2 program for tracer-breakthrough curve analysis for tracer tests in karstic aquifers and other hydrologic systems. EPA/600/R-02/001, US Environmental Protection Agency, Office of Research and Development, National Center for Environmental Assessment, Washington, DC

Uggeri A, Vigna B (1990) Il Tinopal CBS-X: un tracciante alternativo [Tinopal CBS-X: an alternative tracer]. In: Atti XVII Conv. Sp. It., Udine, Italy, Novembre 1990, pp 289-302

Valigi D, Mastrorillo L, Cambi C, Barchi MR, Cardellini C, Checcucci R, Di Matteo L, Frondini F, Mirabella F, Viaroli S, Vispi I (2019) Springs discharge variations induced by strong earthquakes: the Mw 6.5 Norcia event (Italy, October 30th 2016). Rend Online Soc Geol Ital 47:141-146. https://doi.org/10.3301/ROL.2019.25

Wang C-Y, Liao X, Wang L-P, Wang C-H, Manga M (2016) Large earthquakes create vertical permeability by breaching aquitards: increase of vertical permeability after large earthquakes. Water Resour Res 52:5923-5937. https://doi.org/10.1002/2016WR018893 